\title{
CONSTRUCTION OF THE EARNINGS AND \\ BENEFITS FILE (EBF) FOR USE WITH \\ THE HEALTH AND RETIREMENT SURVEY
}

\author{
Olivia Mitchell \\ Jan Olson \\ Thomas Steinmeier
}

NBER Working Paper 5707

\author{
NATIONAL BUREAU OF ECONOMIC RESEARCH \\ 1050 Massachusetts Avenue \\ Cambridge, MA 02138 \\ August 1996
}

The authors gratefully acknowledge the helpful assistance and comments of Benjamin Bridges, Tim Cheney, David Howell, Mike Leonesio, and Larry Smith, and research support from Texas Tech, the Wharton School, and the University of Michigan. Programming assistance was furnished under a National Institute on Aging Grant to the University of Michigan's Institute for Survey Research. Opinions are solely those of the authors, and do not represent the views of the institutions with which they are affiliated, or the National Bureau of Economic Research. This paper is part of NBER's research programs in Aging and Labor Studies.

(C) 1996 by Olivia Mitchell, Jan Olson and Thomas Steinmeier. All rights reserved. Short sections of text, not to exceed two paragraphs, may be quoted without explicit permission provided that full credit, including $\odot$ notice, is given to the source. 


\title{
CONSTRUCTION OF THE EARNINGS AND \\ BENEFITS FILE (EBF) FOR USE WITH \\ THE HEALTH AND RETIREMENT SURVEY
}

\begin{abstract}
Analysts using the Health and Retirement Survey (HRS) often require information on earnings, labor market attachment, and social security benefits in order to better understand the factors affecting retirement and well-being at older ages. To this end, several derived variables were constructed and documented in the Earnings and Benefits File (EBF) described here. The EBF provides a set of summary earnings, employment, and social security wealth measures for a subset of HRS respondents in Wave 1 of the survey, for whom administrative records are available.

The EBF, a restricted data file, is available from the University of Michigan's Institute for Social Research for matching only with versions of the HRS containing geographic detail no finer than the Census Division level. Interested users should contact hrsquest@umich.edu by email for further information on access to the data.

Olivia Mitchell

Department of Insurance

\& Risk Management

University of Pennsylvania

The Wharton School

3651 Locust Walk, 307 CPC

Philadelphia, PA 19104-6218

and NBER

MITCHELO@WHARTON.UPENN.EDU

Jan Olson

Office of Research, Evaluation \& Statistics

Social Security Administration 6401 Security Boulevard

Baltimore, MD 21235
\end{abstract}

Thomas Steinmeier

Department of Economics

Texas Tech University

Lubbock, TX 79409 


\section{Construction of the Earnings and Benefits File (EBF) for Use With the Health and Retirement Survey}

This paper documents the Earnings and Benefits File (EBF). The EBF is a restricted dataset created for researchers working with the Health and Retirement Survey (HRS) under a set of limited access conditions. The EBF and all derived variables contained therein are intended for research purposes only, by registered users of the public use file of the Health and Retirement Survey, and may be linked only with HRS files containing no geographic detail below the Census Division level. ${ }^{1}$

Details on the rationale for, and definitions of, constructed employment, earnings, and social security wealth variables in the $\mathrm{EBF}$ are provided, as well as a bibliography for those wishing additional information on the rules by which social security earnings data are used in calculating benefits. The EBF contains information derived for respondents of the 1992 Health and Retirement Survey who authorized the University of Michigan's Institute for Social Research to obtain administrative records from the Social Security Administration. The EBF is described below, first in conceptual terms in Part I, and then in more technical detail in Part II. Appendices contain a detailed layout of variables and codebook for the data file along with additional descriptive statistics.

\section{A General Description of EBF Variables}

The Earnings and Benefits File (EBF) contains three types of variables, aimed at meeting specific data needs of the research community working with the Health and Retirement Survey. First, HRS researchers often desire summary measures of labor market attachment, particularly useful for modeling retirement and saving patterns. Second, researchers often require information on aggregate earnings, measures of interest in their own right and also of use to those assessing respondents' retirement saving. Third, researchers need computed social security wealth variables

\footnotetext{
${ }^{1}$ Readers interested in obtaining detailed information about social security rules should consult the Bibliography for citations. The SSA world wide web site also provides useful information and references to social security data and rules (http://www.ssa.gov). The EBF is a restricted file and users are prohibited from linking the EBF dataset to any HRS file containing identifiers below the Census Division level. Questions regarding the EBF and HRS datasets should be directed by e-mail to hrsquest@umich.edu.
} 
for studies of retirement behavior, and preparedness for retirement. In the context of the Health and Retirement Survey, first fielded in the year 1992, it is useful to have measures of social security wealth as of that year for comparability purposes with other wealth measures obtained at that interview date.

We have constructed measures of these three types of variables in the EBF dataset, derived only for age-eligible HRS respondents who authorized the release of earnings and benefit data to the University of Michigan's Institute for Social Research. Specifically, only HRS respondents and spouses age 51-61 in 1992 were eligible for inclusion in the EBF file. In this section we describe in general terms the nature of the data creation effort, and further technical details follow in Part II below.

A. Creation of Employment Summary Data in the EBF

The EBF contains a variety of employment summary measures created for Health and Retirement Survey respondents. 'These are derived from administrative records supplied by the Social Security Administration (SSA), in accordance with agreements signed between the Institute for Social Research (ISR) at the University of Michigan and the SSA. Of the HRS survey respondents asked to sign a permission form in 1992 allowing access to their earnings and benefit records at SSA, some $75 \%$ complied with the request. ${ }^{2}$ ISR provided identifiers to SSA, and individual earnings records were obtained for cases with matching identifiers. A final match rate of $66 \%$ of the entire Wave 1 HRS sample was obtained. If no permission was obtained, or if a match could not be generated, no employment variables were generated in the EBF file for that case ID.

Table 1 summarizes several of the labor market attachment variables included in the EBF. The sample included in this Table covers individuals who were not in receipt of disability benefits from social security as of 1991 , and who had nonzero earnings at some point in their careers. ${ }^{3}$ One

\footnotetext{
2 These figures refer to the HRS Wave 1 respondents. In Waves 2 and thereafter additional respondents supplied permission forms, but these respondents have not yet been included in the EBF dataset supplied with this release of the EBF file.

${ }^{3}$ Respondents with no positive covered earnings are excluded from the EBF file. Some of these never worked for pay, but others probably worked in noncovered sectors. These latter sectors have
} 
summary measure indicates how many years a respondent's record showed zero covered earnings by decade of age from age 20-29, 30-39, ... to age 80-89 (see variables 44-50 in Appendix A). Only the years 1951 through 1991, inclusive, are used in this computation. If the respondent's current age was part-way through a decade at the time of the HRS survey, only the relevant years "at risk" are included in the count. Thus, for instance, a 52 -year old respondent would have a value of at most 3 years in the column pertaining to the number of years with zero covered earnings from age 50-59.

Descriptive statistics on this variable by sex and marital status appear in Table 1 for respondents who had had some positive covered earnings over their lifetimes. ${ }^{4}$ Here we see that men with at least some nonzero earnings in the HRS cohort devoted 80-90 percent of their potential work years in covered employment, whereas women with nonzero earnings devoted about half the time in covered jobs during their twenties and thirties, with the fraction rising to 60-80 percent thereafter. The fraction of time spent in covered employment varies with marital status: more married than nonmarried men were in covered employment all their lives, whereas more nonmarried than married women were in covered jobs.

See Table 1. Descriptive Statistics on EBF Covered Employment Variables

A different variable measuring respondents' length of time working under the social security system focuses on total quarters of coverage (QC's), or the number of quarters an individual worked in jobs covered by social security rules. Specific numbers of quarters of coverage (QC's) are needed for establishing eligibility for social security benefits; persons reaching age 62 after 1990 , for instance, must have 40 quarters of coverage to be insured for Social Security retirement benefits. Historically, QC's referred to earnings in a calendar quarter, but more recently, one quarter of coverage has been credited for a specified amount of earnings. For example, in 1992, a worker was entitled to a quarter of coverage for each $\$ 570$ in earnings in covered employment, up to 4 per year;

narrowed over time, but most often would be thought of as government (e.g. federal, state, and local), agricultural, and nonprofit workers.

4 Tabulations in Table 1 are weighted by HRS sample weights. Some HRS respondents do not have covered earnings reported in the administrative records, since their jobs were not covered by social security in times past. For a discussion of covered and uncovered jobs see Myers (1991). 
that figure is indexed over time (SSA 1992, Table 2.A.7). For the EBF datafile, quarters of coverage requirements in the past were computed by the ANYPIA software program. This is a computer program prepared by the Office of the Actuary, Social Security Administration, that incorporates current as well as historical social security rules relevant to HRS respondents (Office of the Actuary 1995).

The EBF reports total quarters of coverage for each individual, as well as quarters of coverage over each two-year period from 1982 through 1991. Table 1 summarizes the total number of quarters reported in covered employment (variable 30; see Appendix A), the number of covered quarters by two-year pairs between 1982-1991 (variables 32-36), and our computation of the total number of years in covered employment between the ages of 20 and 50. As before, the employment variables indicate that married men have the highest numbers of years in covered employment between age 20 and 50 (26 years) as well as total quarters in covered employment (125) compared to nonmarried men (25 years, 115 quarters) as well as married and nonmarried women (16 years, 72 quarters; 18 years and 85 quarters respectively). Both men and women averaged 5-7 quarters of coverage within the last several pairs of years leading up to the HRS survey.

Also included in the EBF is a variable (31) indicating the individual's eligibility status for the Social Security Disability Insurance program as of yearend 1991. Table 1 shows that most married men (84\%) and nonmarried men (75\%) are eligible for SSDI based on their own work record, whereas somewhat fewer married women (59\%) and nonmarried women (72\%) are eligible. As is clarified in Part II of the discussion, any HRS respondents in receipt of Disability Insurance payments at the time of the survey have no social security retirement benefits computed in the EBF 
(but their earnings and employment are shown). ${ }^{5}$ Individuals receiving DI benefits are therefore excluded from computations in Table $1 .^{6}$

\section{B. Computation of Aggregate Earnings Data}

As described above, QC's measure the work attachment requirement for Social Security insured status. Once eligible, retiree benefit amounts are based on the respondent's average longterm covered earnings. Specifically, the number of years in the averaging period equals the number of full calendar years after 1950 (or, if later, after age 21) and up to the year in which the worker attains age 62, becomes disabled, or dies--generally minus 5 "dropout" years. For most HRS respondents, the result is 35 years. For the EBF, the Average Indexed Monthly Earnings (AIME) amount was computed using the ANYPIA program (Office of the Actuary, 1995).

To compute the respondent's current AIME (that is, based on earnings through 1991), the algorithm used covered earnings from 1951 to 1991, recorded up to the taxable maximum earnings ceiling in the administrative records file supplied by the Social Security Administration. (In 1992 this maximum was an annual $\$ 55,500$; for historical amounts, see SSA, 1995, Table 2.A.3). The program then indexes earnings up to age 60 by economy-wide average wage increases; for example, earnings in 1951 were inflated by a factor of almost 9 to convert them to 1992 dollars. Subsequently the respondent's highest indexed earnings are averaged after eliminating the requisite number of dropout years (see Part II for a more detailed discussion). This computation yields the respondent's current AIME amount, in $\$ 1992$ (variable 5). Zero earnings years -- including imputed future zeros - are included as necessary in the AIME calculation. ${ }^{7}$

${ }^{5}$ As noted below, disability benefits are not included in the EBF file.

${ }^{6} \mathrm{DI}$ recipients are identified (variable 4 is set to 1 ) and they have a missing value code $(-9)$ inserted in lieu of social security benefit amounts in the social security benefit fields (variables 9-29 in Appendix A). In this way, DI recipients can be distinguished from those ineligible for benefits due to insufficient quarters of coverage; those not eligible to receive social security benefits have a 0 in their benefits variable fields (variables 9-29). If a DI recipient was married, no benefit is computed for that person's spouse either, and a missing data value (-9) appears in variables 9-29.

' Users should note that the respondents' consent agreements allowed the provision only of records to date and annual earnings before 1951 are not available in electronic form at SSA. 
Two other AIME measures were also created (but not retained in the EBF), namely the AIME that the respondent would have had at the early, and also at the normal, retirement age. Because some HRS respondents (and their spouses) were not old enough to be eligible to receive social security retirement benefits in 1992 , it was necessary to project earnings forward in order to determine what these potential AIME amounts might be if they did work to the social security entitlement ages. Each non-disabled respondent's earnings were therefore projected to age 62, which is the earliest age he/she could file for retired worker benefits under social security rules, and also to that respondent's normal retirement age. This normal retirement age is age 65 for older members of the sample, but has been raised to age 67 for those born in 1960 or later, with gradual increases for ages in between. We projected earnings for each person using a weighted average of his/her own earnings over the past five years, corrected for inflation. (Details are given in Part II of this report).

These earnings calculations may be summarized in several ways. Table 2 describes respondents' average annual real taxable earnings by decade of life, computed beginning at age 2029, and running to age 80-89. For each decade of age, average earnings are computed only to the social security taxable maximum, and only over the years in which the individual had nonzero earnings (variables 37-43). Table 2 indicates that average annual taxable earnings while age 50-59 stood at approximately $\$ 27,700$ for married men, with nonmarried men averaging about $\$ 20,500$, nonmarried women about $\$ 14,700$, and married women about $\$ 10,600.8$

\section{See Table 2. Descriptive Statistics on Earnings Variables in the EBF}

Table 2 also replicates the computation representing respondents' current AIME amounts (variable 5), which as noted earlier include zero earnings years as necessary in the calculation. Married men's AIME averages $\$ 1,990$, with nonmarried men close behind at about $\$ 1,570$; married women's lower earnings and fewer years of covered employment no doubt contributed to the lower average AIME of about $\$ 640$, while nonmarried women are higher at about $\$ 840$. Additional information is also provided in the EBF file regarding the twenty lowest earnings years in the AIME

\footnotetext{
${ }^{8}$ Earnings while age 50-59 are averaged only over possible work years in Table 2.
} 
average, arranged in ascending order (variables 51-70; we do not display the results of these computations since lowest earnings tend to be zero in most cases.) These variables are included primarily to allow analysts to update the AIME using survey-reported earnings for 1992 and later. In addition, analysts wishing to compute alternative AIME figures may use these lowest earnings years to recompute AIME values for other retirement dates (Office of the Actuary 1995; Myers 1993)..$^{9}$

\section{Computation of Social Security Wealth Amounts}

Social security wealth variables were generated for $\mathrm{EBF}$ respondents for whom the AIME could be computed, and who were not currently receiving Social Security Disability Insurance (SSDI). ${ }^{10}$ This was accomplished using the ANYPIA algorithm described above, which combines the respondent's AIME with the relevant formula to obtain that person's primary insurance amount, or PIA. The PIA is the monthly amount payable to a retired worker who begins to receive benefits at the normal retirement age (currently, age 65) or to a disabled worker who has never received a retirement benefit reduced for age. The 1992 formula is as follows (the "bend points" are indexed over time):

$$
\begin{aligned}
& \text { PIA }=90 \% \text { of AIME up to } \$ 387 \\
& \text { Plus } 32 \% \text { of excess up to } \$ 2333 \\
& \text { Plus } 15 \% \text { of any excess above that. }
\end{aligned}
$$

If a respondent was not eligible to receive social security benefits based on quarters of coverage through December 1991, the PIA and all social security wealth variables are set to zero (along with the spouse benefits if there was no spouse, or if the spouse was ineligible for benefits based on the respondent's earnings record).

\footnotetext{
9 A different method of summarizing the AIME computations appears in Appendix B, which reports descriptive tabulations of linear regression coefficients for models using as dependent variables computed values of AIMEs and Primary Insurance Amounts (PIA). 10 Retirees may also qualify for other benefits including disability and Medicare payments, among others, but these are not the focus of the present analysis.
} 
Having computed the respondent's PIA, we then derived the social security benefits he/she and his/her spouse (if any) could receive at the retirement ages under consideration. The rules for benefit determination specify that the PIA is the retirement benefit at the normal retirement age. Workers can also receive early retirement benefits (assuming eligibility) at age 62; under the law, early retirees receive a benefit equal to the PIA reduced by 5/9 of 1 percent or $1 / 180$ per month of entitlement before age 65. The normal retirement benefit computations take into account the fact that the full PIA has been payable at age 65 but the normal retirement age will be gradually moved up in the future.

In addition to computing the retired worker benefits, we also derived spouse benefits if the HRS respondent had a spouse and if sufficient data were available with which to compute these. Each member of a married couple is entitled to receive social security benefits based on his/her own earnings record, and perhaps based on the spouse's PIA if such benefits would be higher. (Spouse benefits are generally equal to $50 \%$ of the worker's PIA). Specifically, dual entitlement arises if the woman's (man's) benefit computed on her (his) own earnings record is lower than that computed as a spouse. In this instance, at retirement she (he) will receive a dual benefit reflecting both her (his) own entitlement as well as an additional amount taking her/him to the level she/he is entitled to as a spouse.

To illustrate this point, suppose that a woman is married to a man who is eligible for retired worker benefits from social security based on his own work record. The wife in this case can receive $50 \%$ of his PIA as a spouse benefit if she were age 65 at retirement; if she were $62-64$, her spouse benefit would be reduced by a monthly amount which comes to $81 / 3 \%$ per year she was under age 65. For the EBF complete computation, we also compute the benefits she would be entitled to based on her own work history. 'The computer algorithm inquires which calculation is higher, and associates with the wife the higher of the two benefit amounts. Users of the EBF file should note that the constructed spouse variables in the variable 10-29 series described in Appendix A do not 
distinguish between respondents projected to receive only spouse benefits, and those projected to be dually entitled. ${ }^{11}$

For currently married persons, the ANYPIA code was also used to project survivor's benefits under social security rules. If an eligible worker dies, the surviving widow/er can receive up to 100 percent of the deceased worker's PIA; such benefits, reduced for early retirement, can begin as early as age 60 . Remarriage after age 60 does not result in the loss of benefits.

For nonmarried persons, eligibility for survivor or other auxiliary benefits could not be determined. For example, in the event that a couple was divorced after a marriage of at least ten years, the divorced spouse would be eligible for spouse benefits; after the death of the former spouse, to surviving divorced spouse benefits. Because the HRS did not obtain Social Security Numbers from surviving divorced former spouses in the HRS, we could not compute spouse benefits to which HRS divorced individuals might be entitled. Users of this database should therefore be alert to the possibility that social security benefits derived for divorced persons will be understated. Lilkewise benefits computed for persons widowed at the time of the survey recognize only prospective payments based on their own record as workers, since we cannot compute widow/er benefits to which an HRS widowed individual might be entitled. Evidence suggests the results will underestimate social security benefits and wealth of many widows and divorced women. ${ }^{12}$

\footnotetext{
${ }^{11}$ So for instance, if a spouse's dual entitlement benefit is higher than the benefit she could receive based on her own earnings record, the larger benefit is entered in her husband's variable 14 (see App. A) and a zero is entered in his variable 13. In her record (assuming she is included in the EBF file), the values of her variables would be compatible with those appearing in her husband's file (i.e., her variable 11 equals his variable 14, and her variable 10 equals his variable 13).

12 Using a different data source, the Survey of Income and Program Participation (SIPP), estimates show that a large majority of aged widows receives benefits based on her husband's earnings record. An internal SSA study found that 77.6 percent of aged widows in 1990 who were receiving social security benefits, received benefits based wholly or partially on their deceased husband's earnings record. This suggests that EBF-computed benefits data for nonmarried women will underestimate the eventual benefits that many of these women will receive, since we do not have deceased spouses' earnings records linked to the file. For divorced women the in-house study suggested that approximately 30 percent of divorcees received social security benefits either wholly or partially based on their (deceased) former husbands' earnings records. This suggests that the understatement of likely benefits may be less serious for divorced than currently widowed women.
} 
Having computed these various social security benefit amounts, the question arises as to the best way to summarize their value to the retiree. In the EBF file we have adopted the concept of social security wealth for this purpose, which simply refers to the present value of the social security benefit payable in the form of an annuity from retirement until death. Benefit values after retirement are multiplied by survival probabilities from that age forward, and discounted to 1992 by multiplying by the conditional probability of being alive at that retirement age, given that he/she is alive at his current age in 1992

The social security wealth computation is straightforward for the case of a nonmarried respondent leaving the workforce at age 62 . Mathematically, we simply sum annual benefit amounts payable from age 62 on, multiplied by the survival probability at each age, and divide by an appropriate discount rate. Age-specific mortality rates by birth cohort were supplied by the Office of the Actuary at the Social Security Administration; for the discount rate we use the interest rate profile consistent with the intermediate set of assumptions chosen by the Social Security 'Trustees (Board of Trustees 1995). A similar wealth value can be computed assuming the worker retires at the normal retirement age, by using the AIME and PIA computed as of that age.

Computing social security wealth for married respondents is somewhat more complex, since the system pays different benefit amounts depending on the couple's mortality experience. As long as both members of a couple survive, retired worker and/or spouse benefits can be paid. However when one of the members of the couple dies, the other may receive a survivor benefit if it exceeds the survivor's own retired-worker benefit. ${ }^{13}$ Hence the derivation of social security wealth here requires that the present value computation incorporate retiree, along with possibly spouse and survivor benefits, weighted by the probability of the different outcomes obtaining. Here too, the interest rate profile used is the one consistent with the Intermediate set of assumptions chosen by the Social Security Trustees.

\footnotetext{
${ }^{13}$ Under current social security rules, persons receiving survivor's benefits are sometimes entitled to retired-worker benefits on their own record, and to higher survivor benefits based on their spouse's record. As noted above in the discussion of spouse benefits, these dually entitled beneficiaries are classified in the EBF simply as spouse or survivor beneficiaries.
} 
An overview of the various social security variables created for the EBF file appears in Table 3. This Table reports descriptive statistics on each respondent's Primary Insurance Amount computed in 1992 when the HRS was first fielded based on the respondent's earnings to date, and also two projected PIA amounts using earnings projected to the early retirement age and to the normal retirement age (variables 6-8). For married men, Table 3 indicates that the PIA based on earnings to 1992 totaled approximately $\$ 800$, rising to $\$ 882$ with earnings to the normal retirement age; levels for nonmarried men were, respectively, about $\$ 680$ and $\$ 750$. Women's PIAs are lower, rising to $\$ 420$ and $\$ 520$ at the normal retirement age for married and nonmarried women, respectively. ${ }^{14}$

See Table 3. Descriptive Statistics on Social Security Variables in the EBF

The EBF file also supplies three total social security wealth variables. One (variable 9) reflects HRS respondents' entitlements as of 1992 ("current"), filling in future years of earnings to age 62 with zeros. The other two social security wealth values are based on the benefits receivable if the respondent continued to work until the early retirement age (variable 16), and also if he/she worked until the normal retirement age (variable 23). These values are given as household social security wealth variables in the second panel of Table 3 . The present values amount to about $\$ 170,000-180,000$ for married men and women working until their normal retirement age, much more than double the values for nonmarried men and women. The fact that married persons' social security wealth is larger reflects the fact that social security retirement benefits are payable to both members of an eligible couple, as well as survivor benefits if one of the members of the couple should die. By contrast, because of data limitations, the social security wealth computation for a nonmarried individual does not include any survivor or divorced spouse benefit, though as noted above, perhaps as many as three-quarters of the widows may receive a survivor benefit over their lifetimes.

14 Social security wealth variables are also described using linear regression models in Appendix C. 
A clearer idea of the separate computations that are incorporated into a married couple's security wealth figure is also available from Table 3 . Here we report the expected present value of social security retirement benefits that an eligible respondent and spouse can collect based on his/her own earnings records, the spouse's earnings records (if any), and as a survivor based on his/her partner's earnings record (if applicable). Thus for example, the wealth value for married men's "respondent" benefits as of the normal retirement age totaled approximately $\$ 89,000$, with the spouse's benefit on her own account totaling $\$ 28,000$; the figures are roughly reversed when the married women are the unit of analysis. ${ }^{15}$

These social security wealth variables will be reasonable representations of the expected future value of benefit payments in most cases, but the reader should be alert to two instances where the EBF projections may be low. ${ }^{16}$ One case arises in the event of a widow/er whose actual future benefits will often be based on the deceased spouse's record. The HRS did not attempt to collect information on the social security numbers of deceased spouses, so for these people, earnings records for deceased spouses (and hence eventual social security survivor benefits) are not available. A second case is that of divorced persons who had been married 10 or more years prior to divorce. Under the regulations, divorced persons may file for benefits based on their former spouses' earnings history. For the purposes of the EBF file, however, we could not compute benefits based on the former spouse's earnings since these earning files were not available to us. Therefore the social security wealth variables in the EBF file may be a substantial understatement of benefits that will likely be received for nonmarried women, and specifically widows/ers and for divorced women who previously had been married for 10 or more years.

Users of the EBF file should also be alert to the point that estimated benefits and social security wealth are also likely to be low for those respondents having had Social Security disability

\footnotetext{
${ }^{15}$ The higher benefit values reported for male as compared to female HRS respondents in Table 3 reflect the fact that HRS age-eligible male respondents are somewhat older on average, as compared to HRS women respondents.

16 Those already divorced or widowed at the time of the HRS survey will have benefit amounts computed based only on their own records, as noted above. No benefits are computed for those in disability benefit receipt status (or their spouses).
} 
benefits in their past. This is because during such periods, SSA protects against the loss of or the reduction in the amount of retirement insurance benefits, by providing that the period during which the person is disabled will generally be excluded from determining either retirement benefits and social security wealth. ${ }^{17}$

\section{Layout of the EBF}

In this section we offer an idea of the EBF layout, with the idea that a general reader may be satisfied with this description of the EBF variables along with the detailed variable list for the file supplied in Appendix A. Part II, below, provides more detailed file construction information.

The EBF contains one record for each individual in the HRS from whom a valid permission form was obtained, and who had nonzero earnings at some point in his/her career. Each person in the file is identified by a case ID, that matches the same variable in the HRS records and is the variable for linking these records to the HRS data set. ${ }^{18}$ For individuals who were married at the time of the HRS interview, there is also a spouse ID, which is the HRS case ID of the record of the spouse. This variable has a value of 0 if there is no spouse, and a value of 99999 if there was a spouse but the spouse does not have a record in the main HRS data set. ${ }^{19}$ All other variables are as described in Appendix A, with the caveats discussed above.

\section{Technical Discussion of Algorithms and Assumptions in the EBF}

This section is intended to provide additional technical details on how the EBF dataset was constructed. In addition to the case ID variables noted above, the other variables in the record are grouped into three categories and discussed in turn. These three sets of variables are: labor market attachment variables, earnings aggregates, and measures of family social security wealth.

\footnotetext{
${ }^{17}$ For each of these cases, the EBF total social security wealth variables can be modified using social security benefit files in conjunction with the earnings records.

${ }_{18}$ The EBF can be linked only to HRS data containing no geographic detail below the Census Division level. Information about access to the restricted files is available over email from hrsquest@umich.edu.

19 This might occur if, for example, that spouse did not participate in the survey, or did not agree to permit the attachment of earnings record data to his or her file. Social security wealth variables are imputed using the hot deck procedure described in Part II.
} 


\section{A. Labor Market Attachment Variables}

The EBF dataset contains three groups of variables measuring labor market attachment. Variables 44 to 50 indicate the number of years by age decade that the individual reported zero earnings. These decades are the same decades used in calculating the average earnings by decade, and the same limitations apply. Specifically, only the years between 1951 and 1991, inclusive, are included. This means, for example, that an individual who is 56 years old in 1992 and who had four years of non-zero earnings and two years of zero earnings in the 1986-1991 time period will have a value of two assigned to variable 47. (Data in Table 1 correct for the fact that the number of potential years of work varies by respondent age.)

A second variable indicates the respondent's total quarters of coverage (or credits) as of yearend 1991. This is needed to establish whether the individual is presently insured under the old-age retirement program, or whether he or she may become insured on the basis of future work. The respondent's total quarters of coverage at the end of 1991 appear in variable 30. For workers attaining age 62 in 1991 or later, 40 quarters of coverage are required to be eligible for old age benefits when they retire. ${ }^{20}$ Researchers can update the total quarters of coverage after 1991 using the work status and earnings figures available in the HRS surveys in 1992 and later. An individual receives one quarter of coverage for each $\$ 570$ of earnings in 1992 , an amount adjusted annually according to the average annual earnings index.

A third group of variables is useful for establishing whether the individual is currently insured under the disability insurance program. Whether the individual was currently insured at the end of 1991 is given by variable 31. In most cases, the individual is required to be fully insured and have 20 quarters of coverage (or credits) in the previous 10 years to be disability insured. ${ }^{21}$ Variables 32-36 can be used to update the disability insurance status at two year intervals for the

\footnotetext{
${ }^{20} \mathrm{~A}$ person is fully insured if he or she has at least 1 credit for each calendar year after 1950 , or if later, after the year in which he or she attained age 21 , and prior to the year in which he or she attains age 62 (see SSA, various years).

${ }^{21} \mathrm{~A}$ person has disability insured status if he/she has at least 20 credits during a 40 -quarter period ending with the quarter in which the individual is determined to be disabled; and is fully insured as well (see SSA, various years).
} 
following ten years, again using work status and earnings figures from the household HRS surveys in 1992 and later. For example, if an individual had 3 quarters of coverage in 1982-1983 and 18 quarters of coverage in the period 1982-1991, and if the household survey indicates that the individual had 8 quarters of coverage in 1992 and 1993, then we can infer that the individual had 23 quarters during 1984-1993 (18 plus 8 minus 3), making him or her disability insured at the end of 1993.

A final entry in the labor market variable group indicates whether the individual was receiving social security disability insurance benefits as of December 1991. This is variable 4, taking a value of 1 if the individual was receiving disability benefits as of December 1991 and a value of 0 if he or she was not on disability at that time. Unlike most of the other variables in this file, this variable comes not from the summary earnings record but from the benefits record. If the individual was collecting social security disability as of December 1991, all variables described in the next two sections (average monthly earnings, primary insurance amount, social security wealth, etc.) are all set to -9 . This is because the algorithms that are used to calculate these variables for the dataset are appropriate only for old-age benefits for persons without prior entitlement to disability benefits. Spouses of workers receiving social security disability insurance benefits are included if they are ageeligible respondents in their own right.

\section{B. Earnings Aggregates}

Variables 37 to 43 in the EBF file provide the average real taxable earnings by decade of life. These decades are age decades, not calendar decades, and run from ages 20-29 to ages 80-89. For each decade, the average is calculated using only the years in which the individual had positive earnings; years in which there were no earnings are excluded from the average. Further, these are real earnings, which means that each annual earnings amount is indexed to 1992 using the consumer price index (CPI-U). The indexing is done prior to averaging. The user is reminded that no annual earnings are available in the social security records before 1951 or after 1991. Further, only taxable earnings up to the maximum amount subject to social security taxes are available in 
these records, and zeros appear in the record for respondents too young to have worked the full decade.

C. Derived Social Security Retirement Benefit Variables

Social security benefits for HRS respondents are calculated in three stages. First, the Average Monthly Indexed Earnings (AIME) amount is calculated for everyone for whom earnings data are available, using the number of years of earnings as specified in the social security law. If a respondent does not have enough positive years of earnings, zeros are filled in for the remaining years. Next, the Primary Insurance Amount (PIA) is calculated from average monthly earnings using a formula that depends on when the individual turns age 62. Finally, an adjustment factor reflecting early or late retirement is applied to the PIA to determine the benefit amount, as required.

Variable 5 lists the calculated AIME amount based on earnings through 1991, rounded to the nearest $\$ 10$; for this computation zeros are filled in for years between 1991 and the year the respondent turns age 62 . This AIME figure is calculated by a program created by the Social Security Administration called ANYPIA, that incorporates the many changes that Congress has made in social security law over the years (Office of the Actuary 1995).

For the AIME computation, earnings before the age of 60 are indexed upward to age 60 by a factor calculated from SSA's average annual wage series. Earnings after age 60 enter the average on an unindexed basis. In general, for persons without current or prior disability, the number of computation years equals the years after 1950 (or age 21 if later) to age 62, excluding 5 'dropout' years. For HRS respondents who turned 60 in 1992 and before, earnings before age 60 are indexed according to the average annual wage series, and the high 35 years are averaged. For respondents who turn 60 after 1992, the indexing amount was not known in 1992. For these individuals, earnings are indexed to 1992, and the high 35 years are averaged (including zero earnings years, if any)..$^{22}$

22The average earnings computation for workers who attained age 62 prior to 1978 is computed slightly differently (see SSA, various years or the Social Security worldwide web page at www.ssa.gov). 
The EBF also contains the variables necessary to update the AIME amount based on earnings in 1992 and subsequent years as reported in the household surveys, at least for those individuals who attained age 62 in 1979 and after, and are thus governed by the indexed earnings formula (SSA, Table 2.A8). Variables 51 to 70 contain the lowest 20 years of earnings in the AIME computation, arranged from the lowest year and in ascending order. The amounts reported are indexed (and not nominal) amounts, meaning that they are indexed to age 60 if the earnings were before age 60 and the individual had reached 60 by 1992, or if the individual was under age 60 in 1992, they are indexed to 1992 . The indexing rules are the same as those that are applied in computing the average indexed monthly earnings figure itself. Note that these variables may contain a number of zero amounts, which signifies that the individual thus far had positive earnings for fewer than the number of computation years. Also, this entire set of 20 variables is set equal to zero if the individual reached age 62 before 1979 , in which case the monthly earnings were figured using unindexed earnings rather than indexed earnings.

To illustrate the updating process, suppose that we obtain a 1992 earnings figure from the household survey, and we want to see how this affects the AIME. First, the earnings amount is indexed to age 60 or 1992 , as appropriate. Then the indexed amount is compared to the low year in the average (the figure in variable 51). If the new amount is less, then the 1992 earnings do not affect the AIME. If it is greater, then the difference, divided by 35 (or the number of computation years), is added to the AIME (variable 5). This is equivalent to substituting the 1992 figure for the low indexed amount in the average. For additional years of earnings after 1992, the process is repeated. The fact that the 20 lowest indexed earnings years are reported implies that, based on future observed earnings in the household survey, the AIME figure can be updated at least through the year 2011 .

Next comes estimated primary insurance amounts (PIA), reported in variables 6-8. The PIA in variable 6 is based on earnings though 1991 and the AIME reported in variable 5 . If the individual was 62 or older in 1991, the amount in variable 7 is the same as in variable 6 . Otherwise, the PIA in variable 7 is based on projected earnings through age 61 , with the projection method 
discussed later in this section. Variable 8 is similar to variable 7 , except that earnings are projected through the year immediately before the normal retirement age. In calculating variable 8 , it is assumed that the individual applies for benefits at the normal retirement age.

The PIA calculation is done by the ANYPIA program. The formula applied to the AIME figure is determined by the year the individual attains $62 .{ }^{23}$ Those individuals who turn age 62 in or after 1978 have their PIA calculated using an AIME that depends on the year they turn 62 (variable 5). For instance, the formula for individuals who turn 62 in 1986 is $90 \%$ of the first $\$ 297$ of average indexed monthly earnings, $32 \%$ of the next $\$ 1493$, and $15 \%$ of anything beyond that. These "bend points" are indexed to the national average annual wage level, but there are always just three segments in the formula. As before, this formula gives the primary insurance amount for the year the individual turns 62 , and the resulting amount is indexed upward every year by the cost of living index.

For individuals who attain 62 in or before 1992, the bend points are known (e.g. SSA 1995, Table 2.A.11), and the PIA indexed to 1992 is reported in variable 6 . For individuals who attain 62 after 1992, the AIME is indexed to age 60 (if necessary) and the bend points are indexed to age 62 , both using the increases in the national average annual wage index projected by the Social Security Administration. The PIA is calculated using the projected formula applied to the projected average indexed earnings, giving a PIA value that would apply to the year the individual turned 62 . The resulting amount is then deflated to 1992 using the projected increases in the consumer price index. This gives the value of the primary insurance amount in 1992 dollars and is thus comparable to the amounts calculated for individuals who reach 62 in or before 1992. The assumptions used to forecast the national average annual wage and the consumer price index are the "intermediate" assumptions offered by the Office of the Actuary of the Social Security Administration and are reported in Table 4. ${ }^{24}$

\footnotetext{
${ }^{23}$ Special rules apply if the individual turned 62 before 1979 (see SSA, various years). What is reported in variable 6 is the primary insurance amount as of 1992 , reflecting the cost of living increases since the individual first became eligible.

24 The consumer price index is the CPI-W, or the index for urban wage earners and clerical workers.
} 
See Table 4 - Wage and Inflation Projections

As mentioned before, the primary insurance amount in variable 6 is calculated solely on the basis of the earnings in years up to and including 1991 (with zeros filled in to age 62 as necessary). The amounts in variables 7 and 8 project future earnings up to the year before the retirement age (early for variable 7 and normal for variable 8) in cases where the individual was under that age in 1991. The method of projecting these future earnings adopted for the present purposes is to compute for each HRS respondent a weighted average of his or her own recent earnings and to project these earnings into future years.

More specifically, earnings in the five-year period 1987-1991 are indexed to 1991 levels using the National Average Wage Index of the Social Security Administration. The indexed wages are then averaged, with the 1987 through 1991 single-year earnings given weights of $1,2,3,4$, and 5 , respectively. This procedure thus places more weight on more recent earnings. This weighted average is then indexed upward to each year up to and including the year before the individual reaches the early (for variable 7) or normal (for variable 8) retirement age, using the National Average Wage Index found in Table 4. The resulting wage series is then used to calculate a primary insurance amount in exactly the same way as before, and the resulting values appear as variables 7 and 8.

This procedure gives reasonable results for individuals with a steady work history who are planning to work at least until age 62 . However, data users must be alert to the fact that there are several cases where it may not give good results. For instance, if a woman has an intermittent work history, her earnings in the last five years may give only a very noisy indication as to her work intentions for the future years. In such a case, it is probably difficult to produce an algorithm which will give accurate projections of the course of her future earnings. Another case where the algorithm is susceptible to error is if the individual has recently retired within the last year or two. The trouble here is that it is difficult to know whether the fact that there are no earnings in the last year or two signifies a permanent retirement or a temporary interruption of employment. Thus, users are cautioned that particularly for respondents with intermittent work histories and individuals who 
may have recently retired, the projected primary insurance amount and the projected social security wealth variables should be regarded as being subject to substantial potential errors.

\section{Computed Social Security Wealth Variables}

As described above, we have computed social security wealth several different ways for the EBF dataset. Our intention was to make these variables as comparable as possible, in conceptual terms, to the other measures of wealth reported in the HRS.

Three versions of social security wealth appear in the EBF. The first (variable 9 ) is the expected present value of benefits already accrued by the respondent, based on his covered earnings up to and including 1991. (This computation assumes the person would have no covered earnings between 1992 and the year he turns age 62 ; a zero is entered if the person would not be eligible for benefits based on this work record). The second and third wealth variables (positions 16 and 23) represent the expected present value of benefits based on a respondent's projected earnings if he/she was younger than age 62 at the time of the survey, up to the year before attaining the early or normal retirement age. These projections, described in the previous section, are carried out for all individuals and for both spouses of a married couple (with caveats to be explained below). In the case of a married couple, if one spouse was at or over the retirement age and the other was under it, the projection is done only for the spouse who was under the retirement age, and the full earnings through 1991 are used for the older spouse.

Social security wealth calculations depend on a number of assumptions. One set of assumptions has to do with mortality, since the calculation multiplies the expected benefit each year times the probability that the individual will live to collect it. In the next section we discuss the specific mortality tables used in creating the EBF file. In all cases, social security wealth calculations are discounted back to the respondent's age in 1992, taking into account the conditional survival probability of the person living to that future age, given his/her current age. Another set of assumptions has to do with the expected future paths of wages, prices and interest rates. Needless to say, there are differing opinions of the likely future course of these variables, but we have chosen to evaluate the social security wealth on the basis of the "intermediate" assumptions supplied by the 
Board of Trustees of the Federal Old-Age and Survivors Insurance and Disability Insurance Trust Funds (Board of Trustees 1995, p. 56). ${ }^{25}$

The wealth calculations were handled as follows. For each nonmarried respondent, we consider each year beginning with the year 1992. For each member of a married couple, benefits are computed for each spouse separately; here we consider each year beginning with either age 60 (which is the youngest age a married individual could collect surviving spouse benefits) or the year 1992, whichever is later. For married persons, two calculations are undertaken, depending on whether the partner is or is not projected to be still living; we weight each calculation by the probabilities (as calculated from the mortality tables) that the individual is still living and the partner is either living or not, respectively. For every year in which the spouse is still living, the approach was to first ask whether that spouse is age 62 or older. If he or she was under 62 years old, that individual may only receive benefits based on his or her own earnings record. If the spouse is 62 years old or older, then we compared the benefits the retiring individual could receive on the basis of his or her own earnings with the amount that he or she could receive as a spouse based on the spouse's earnings. The individual would then be assigned the higher benefit amount. ${ }^{26}$

To determine the benefits that would be available on the basis of a respondent's own earnings history, the PIA in nominal dollars is calculated by the ANYPIA program on the basis of the earnings history. For persons older than the retirement age in 1992 , we assume that they became entitled (that is, they were eligible and applied to receive benefits) in the first year that at least some benefits would have been received, but in no case later than the normal retirement age that would apply to their birth cohort. For individuals younger than the retirement age, we assume that they will first become entitled at the early retirement age of 62 (for variables 9 and 16), and at the normal retirement age (for variable 23), assuming they have sufficient quarters of coverage to be entitled to

25 The 1995 report was the latest year available at the time that these wealth variables were calculated.

26 In generating variables 16 and 23, the individual is assumed to begin collecting benefits when he or she first applies for social security benefits. This is held to be the early retirement age for variable 16 and the normal retirement age for variable 23 . In addition, the individual cannot collect spouse benefits until the spouse has applied as well, in accordance with the rules (Myers 1993). 
receive benefits. ${ }^{27}$ The benefit amount is then the product of the primary insurance amount times any reduction or augmentation factor that depends on the person's age of retirement. ${ }^{28}$

In addition to benefits to which a respondent might be entitled on his or her own record, a married respondent might also be entitled to benefits as a spouse of a retired worker. Where possible, the EBF file reports these spouse benefits, calculated based on the other partner's earnings record as of the previous year by the ANYPIA program for married couples. ${ }^{29}$ The basic spouse benefit is 50\% of the husband's (or wife's, as relevant) PIA. A reduction factor is then applied which is determined by when the individual would have first started collecting spouse benefits. The reduction factor, calculated monthly, totals 8.33 percentage points for each year before age 65 that the individual first collects spouse benefits; that is, the benefit is reduced by $25 / 36$ of one percent multiplied by the number of months preceding age 65 . This reduction factor is scheduled to be modified when the normal retirement age increases from its present level of 65 . The spouse benefit is then $50 \%$ of the partner's PIA multiplied by the spouse reduction factor. ${ }^{30}$ For married respondents, therefore, the EBF reports a total benefit due the individual as either the benefit based on his/her own earnings record, or the spouse benefit based on the spouse's earnings record, whichever is higher. (As noted above, in dual entitlement cases, benefits are classified in the EBF as

27 If a respondent was not entitled to social security benefits based on his own work record as of his age in 1992 his social security wealth benefit variable 10 would be set to zero; similarly for benefits based on work until age 62 (in which case variable 17 would be set to zero), and until the normal retirement age (and variable 24 would be zero).

${ }^{28}$ Normally, the benefit would be subject to the earnings test which may reduce benefits for those continuing to earn after receipt of benefits. The potential benefit may also be increased because of the delayed retirement credit if the individual has worked after the normal retirement age and lost some benefits to the earnings test. The earnings test does not apply after 70 years of age. Here, earnings are imputed only before 1992 or if the individual is under the retirement age; benefits are calculated only on or after 1992 and if the individual is above the retirement age. As a result the wealth program assumes no earnings in years after the individual becomes eligible for that benefit. 29The data user should understand that there are some cases where spouse benefits for HRS respondents married at the time of the 1992 survey could not be computed based on the married parties' earnings records; see Section $F$ for hot deck and missing data cases.

${ }^{30}$ In reality this benefit would be subject to earnings tests, both one based on the individual's own work and also one based on the work of the partner (since the individual cannot collect benefits in any month the partner does not also collect benefits). However, the wealth program assumes no work past the retirement age as indicated in the previous footnote. 
spouse benefits or survivor benefits as relevant; increasing numbers of women are dually entitled over time)

If the worker is deceased, a widow/er may be eligible both for survivor benefits based on the earnings record of the deceased and for retired-worker benefits based on his or her own record. If the widow(er) is entitled to both, he or she is dually entitled and receives a full benefit based on his or her own record plus a partial benefit based on the deceased spouse's record. The amount of the partial benefit is the difference between the widow/er's own retired-worker benefit and the amount to which he or she is entitled as a widow/er. Because the benefit amount received in this case is equal to the higher, surviving spouse benefit, the variable is identified in Appendix $A$ as the "surviving spouse benefit". The calculations based on the individual's own benefits are exactly the same as in the previous situation.

Unlike other social security retirement benefits, surviving spouse benefits may begin as early as age $60 .{ }^{31}$ For the surviving spouse calculations (variables 12,19 , and 25), there is an additional problem: these benefits may depend on when the partner died. Hence, a separate calculation is made for each possible year of death between 1992 and the year immediately before the year for which the benefits are being calculated, and the weights on the calculated amounts are proportional to the partner's mortality probability in the successive years.

For each possible year in which the retired-worker partner could have died, the calculations require several steps. First, the worker's PIA is calculated based on his/her earnings record up to the year immediately prior to death. Note that if the age at death was younger than 62 , these calculations differ from the regular old-age calculations because there are fewer years in the calculation of average indexed monthly earnings. Next, if the worker was eligible for any delayed retirement credits, these are added to the primary insurance amount. If the worker died before the spouse turned 65, the PIA is subject to a reduction of $5.7 \%$ (not 5.7 percentage points) for each year

\footnotetext{
31 Variable 9 assumes no projected earnings, and the widow/er applies for benefits at age 60 (or immediately, if she/he is older than age 60 ). For variables 16 and 23 the widow/er is assumed to continue his/her employment status until, respectively, the early or the normal retirement age, before applying for these benefits.
} 
the spouse collects survivor benefits before age 65. Again, the calculation of this reduction is modified when the normal retirement age rises above its current value of 65 . Finally, if the spouse had applied for benefits, the surviving spouse benefit would be subject to a limitation that it should not be any larger than the amount payable to the worker had he/she still been alive (as long as this restriction does not lower the benefit below $82.5 \%$ of the worker's primary insurance amount).

In overview, then, for every year that a member of a married couple could collect benefits, the person is modeled as receiving either (a) benefits based on his or her own earnings record or spouse benefits (conditional on the partner being alive), or (b) benefits based on his or her own earnings record or surviving spouse benefits (conditional on the partner being deceased). As noted, those modeled as dually entitled are shown as spouse or survivor beneficiaries. Data for the partner are computed similarly. Finally, the amounts are weighted by the probabilities that the two partners will be individually and/or jointly alive, and the amounts of the two partners are added. These calculations are carried out in nominal terms of the year the benefits are to be collected, and projected using the "intermediate" assumptions regarding wage growth and consumer price index growth..$^{32}$

To form a wealth measure, future benefits are discounted according to the interest rate in the set of "intermediate" assumptions (Table 4), and the discounted amounts summed for all the years that either member of the couple might collect benefits. The wealth measure for unmarried individuals is similar, except that there is no partner, no spouse benefit, and no surviving spouse benefit. The wealth is simply the discounted value of the future benefits based on the individual's own earnings history. All values are reported as of the respondent's current age in 1992, discounted using conditional survival probabilities based on the respondent's current age. ${ }^{33}$

32 If an individual was not eligible for own retirement benefits, his/her own worker benefits would be set to zero. In a married couple, if either spouse was receiving DI in 1991, the wealth variables for both spouses are set to -9 and the AIME and PIA are set to zero. If either partner would be projected to be eligible for benefits by the early or normal retirement age, the relevant wealth variables is positive.

${ }^{33}$ As noted, this will probably underestimate wealth for potentially three-quarters of the currently widowed women, and some unknown fraction of divorced women, inasmuch as we do not have their former spouse's earnings records. 
In the case of married couples, there are additional components for each of these social security wealth variables (variables 10-15, 17-22, and 24-29; these variables are set to zero for nonmarried respondents). One set of variables represents the expected present value of components of social security wealth that the respondent could collect, and others represent the expected present value of components that his or her spouse could collect. Each set of three is comprised of (a) benefits that the individual could collect on his/her own earnings record, (b) spouse benefits that the individual could collect on the basis of the partner's record, and (c) surviving spouse benefits that the individual could collect on the basis of the partner's record if that partner died.

For example, if the wife has a PIA substantially greater than twice her husband's, and if she is younger than her husband, then it is likely that variables $10,13,14$, and 15 in her record would have positive amounts, and variables 11 and 12 would contain zeros. This is because she will collect benefits on her own account but never on her husband's account, while the husband will be dually entitled with the larger amounts received as spouse benefits and surviving spouse benefits rather than benefits based on his own account. However, since the older husband reaches retirement age before she does, he will collect benefits for a few years on his own account until she applies and he is able to collect spouse benefits. The same figures will appear on the husband's record, but the pairs of three variables will be reversed. That is, variables 10-12 will refer to benefits he is expected to collect, and variables 13-15 will refer to variables she is expected to collect.

These component quantities can be combined in different ways for different purposes. For example, if the interest is in an individual's lifetime retirement benefits, then the appropriate combination would be the sum of variables $10-12$ (or alternatively variables $17-19$ or $24-26$ ). This will give the total expected value of the social security benefits that that individual is expected to collect. Alternatively, if a researcher were instead interested in retirement incentives, then variable 
10 should be combined with variables 14 and 15 to give the total expected benefits based on the individual's own earnings history, assuming no change in spouse labor force behavior ${ }^{34}$

The EBF data user must be aware that in a minority of cases, the social security wealth variables computed for the $\mathrm{EBF}$ file are subject to potentially severe measurement problems. Two instances involve individuals who were single at the time of the HRS survey but who were previously married. For such individuals, the social security wealth just described is necessarily based on their own earnings records in the EBF. However, if the individual is a widow or widower, his or her actual social security benefits might in reality be higher if they are computed based on the deceased spouse's record ${ }^{35}$ Alternatively, if the individual had been divorced from a marriage that lasted for 10 or more years, the individual might be eligible for benefits based on the former spouse's earnings record. In neither case were the relevant records for deceased or divorced spouses obtained from the Social Security Administration. In fact, until someone files for benefits, the Social Security Administration does not necessarily know that any two people are linked.

A different measurement problem arises for persons married in 1992 who might divorce, in that spouse's benefits are only payable to married persons who had been married at least 10 years by the time of the divorce. Our computations for elements of social security wealth available to members of a couple assuming that they remain married at least 10 years.

Eventually, it will be possible to fine-tune these wealth measures for divorced and widowed individuals once they begin collecting benefits; for now the best that can be done is to calculate the wealth based on the respondent's own record and to note there may be understatement of benefits for widows or widowers and for divorced women who previously were married for a decade or more. ${ }^{36}$ E. Mortality Data

\footnotetext{
${ }^{34}$ Depending on whether the individual gives full weight to benefits that the spouse will collect after the death of the individual, the researcher may want to alter the relative weights of variable 15 and perhaps variable 14 in the sum.

${ }^{35}$ As noted earlier, three-quarters of aged widows with benefits received survivor benefits based on their deceased husbands' earnings records (unpublished SSA estimate).

36 Widows age 60-61 who were already receiving benefits in the HRS are handled like other widows in the survey, namely their social security wealth was calculated on the basis of their own earnings even if they are already receiving benefits as widows.
} 
The mortality data used in calculating the wealth variables are taken from the Social Security Administration's actuarial projections. ${ }^{37}$ These projections contain, among other things, the estimated probability of survival, by sex, for each year of age up to 120 and for each birth cohort from 1900 to 1980; this time span includes all cohorts of interest for purposes of the HRS.

Summary statistics from these mortality data, reported in Table 5, indicate very strong trends in increasing life expectancy over time. The most dramatic increases in life expectancy are those at birth, but a large part of this increase comes from reduced infant mortality, which is clearly not relevant for the HRS respondents. Even so, there are projected to be non-trivial increases in life expectancy at age 25 and, perhaps more importantly, at age 65 , and it is clear that the percentage of individuals living to very old ages (age 85 or 100 ) is going to grow very rapidly in the coming years, given recent mortality trends.

\section{See Table 5 - Mortality Rates by Cohort}

The EBF user should be aware that these mortality statistics, and the social security wealth variables calculated from them, are population averages by sex and birth cohort. These mortality data are not available separately by race, and they also do not reflect any individual differences which might make individuals perceive their own mortality probabilities to be either higher or lower. Vital Statistics mortality probabilities are calculated separately by race, but they are not projected into the future, and they are only available to age 85 . Given the increasing percentage of the population, particularly women, who survive past 85 , this last limitation is a matter of concern.

Our decision to employ mortality statistics furnished by the Social Security Administration is therefore a compromise. Neither these figures nor those supplied by Vital Statistics reflect all the variables observable by individuals that might plausibly affect individuals' estimates of their own mortality probabilities. Among such factors are peoples' current health status including the presence and severity of disease, family income levels, and whether they participate in any activities or

\footnotetext{
${ }^{37}$ Felicitie Bell in the SSA's Office of the Actuary kindly supplied these data. A comparison of the SSA data with the 1990 Vital Statistics figures (Table 5) suggests that the lower survival rates in the Vital Statistics tables would have resulted in lower social security wealth figures than those reported here.
} 
occupations which elevate the mortality risk. The construction of such individual-specific mortality tables would be a research program in itself, not one which we undertake here. Hence it should be understood that the social security wealth variables reported in the EBF are approximations. Users exploring differences in social security wealth arising from mortality probabilities that differ according to factors other than age and sex should derive their own social security wealth variables.

\section{F. Hot Deck Procedures}

The social security variables just described are calculated for each 1992 HRS respondent for whom the HRS received an earnings record from the Social Security Administration. That is, there is a one-to-one correspondence between respondents' records in the EBF, and the earnings summary file supplied by the SSA to the Health and Retirement Survey. All of the variables except the couple's social security wealth amounts can be calculated from the respondent's own earnings record, and it does not matter whether the record for the spouse is present, or for that matter even whether the individual has a spouse.

The situation is different for a married couple's social security wealth variables, since in this case it is necessary to have a record for the spouse as well. For some 1356 out of 4077 married HRS sample couples, the social security file contains a record for one spouse but not for the other. ${ }^{38}$ This could have occurred either because the spouse did not grant permission to access the earnings record, or because a valid match to the earnings record could not be found at the Social Security Administration. In these cases, for the missing spouse record, we substituted an actual earnings record from another respondent with the same sex and similar levels of earnings and labor force attachment. ${ }^{39}$ This procedure is known as "hot-decking" in the survey literature. We emphasize that in such cases, there is only one record in the summary social security variables file; we did not create

\footnotetext{
38 Some of those without an earnings record had never worked for pay in covered employment. Of the 1356 spouses without social security records for instance, 614 were women.

39 If there were no records which matched exactly the five categories, adjacent cells were searched until a match was found. Adjacent earnings cells were searched first, followed by adjacent age cells and adjacent experience cells. In no case was it necessary to vary earnings, age, and experience by more than one category to find a match. Also, in no case was male record substituted for a female or vice versa, or a record for someone not working in 1992 substituted for someone working or vice versa.
} 
a record for the "hot-decked" or missing spouse's earnings history. Rather, this hot deck record was used only to impute the family social security wealth variables for the respondent for whom we did receive a social security earnings record. (It will be recalled that respondents surveyed by the HRS, who were outside the HRS age range of 51-61 in 1992, appear in the HRS by virtue of being married to age-eligible spouses. The EBF contains records only for age-eligible respondents, as noted above, though family social security wealth computations include benefit estimates for age-ineligible spouses).

For the hot deck procedure, we relied on all the earning records received from the Social Security Administration. Each non-missing record was assigned to a single cell in a five-way classification table, based on the information the respondent gave in the household survey. The table was chosen to reflect the five variables that we believed were closely associated with different levels of average monthly earnings and, therefore, potential benefit amounts. These five variables are: sex (male or female), work status at the time of the 1992 interview (working or not working), 12 categories of age in 1992, 26 categories of annual earnings, and 6 categories of observed work experience. ${ }^{40}$ For individuals who were working at the time of the 1992 interview, annual earnings are taken as the reported earnings for the calendar year 1991, while if the individual was not working at the time of the 1992 interview, annual earnings are calculated from the wage (which could be given as an amount per hour, per week, per month, or annual) in the last job. Total observed experience is the sum of the tenures in the current job in 1992 (if employed at the time), the last job (if not employed at the time), and up to three previous jobs that lasted for more than 5 years. ${ }^{41}$

\footnotetext{
40 The age categories used were five years in width for ages between 25 and 74 . Individuals 24 years old and younger were grouped into a single category, as were people 75 years and older. The earnings categories are $\$ 2,000$ wide between $\$ 0$ and $\$ 24,000, \$ 3,000$ wide up to $\$ 42,000, \$ 4,000$ wide up to $\$ 50,000, \$ 5,000$ wide up to $\$ 60,000$ and $\$ 10,000$ wide up to $\$ 100,000$. Earnings over $\$ 100,000$ were grouped into a single cell, since this is considerably above the social security taxable maximum. The experience categories are 0-5, 6-10, 11-20, 21-30,31-40, and 41+ years.

${ }_{11}$ The HRS did not ask respondents directly about the total number of years they had been employed in all jobs, so experience must be proxied by the total experience in jobs reported in the survey.
} 
The rationale for the earnings and experience variables is fairly clear: since the average monthly earnings figure in the social security calculations depends on the average earnings and the number of years the individuals have been in covered employment, it is important to take this information into account when matching. Age is important in considering whether a given number of years of experience represents a large or moderate percentage of the number of years of eventual experience when the individual retires. Also, sex is important if it is likely that participation patterns vary considerably between men and women, even for those with similar earnings. Finally, it probably makes a considerable difference, especially for the projected wealth variable, whether the individual is or is not currently working. The projected earnings of a married women who has worked in the past but who is not currently working may well be quite different from those of a married women with a same average earnings but who is continuing to work.

Having grouped all available earnings records into this five-way table, the records were then randomized within each cell of the table. Since there are 7,488 potential cells in the table, and we have 8,394 earnings records, each cell has on average a little more than one record. Then, when we have an individual with a social security earnings record but no matched record for the spouse, we select a "donor" HRS household file to construct the gender, 1992 work status, wage, and experience variables for the spouse, and use a randomly chosen record from the same age-gender-work statuswage-experience cell to represent the spouse's missing record. When necessary, the wage, experience, and/or age cells are broadened until a match is found. Again, this matched record is used only to construct measures of family social security wealth for those individuals for whom we do have an actual earnings record.

\section{Conclusion}

Researchers using the Health and Retirement Survey require information on earnings, labor market attachment, and social security benefits, in order to better understand the factors affecting both the retirement decision and well-being in old age. It is anticipated that analysts will find the aggregated variables in the restricted Earnings and Benefits File to be of substantial 
use toward this end. It is expected that the average user will be able to use these created variables as they are; other analysts will desire to combine these variables along with their own algorithms to derive alternate outcomes.

The Earnings and Benefits File, along with full documentation and datafiles from the Health and Retirement Survey, is a restricted file available from the University of Michigan's Institute for Survey Research under a series of limited data access conditions. It can be merged only with versions of the HRS that contain no geographic detail below the Census Division level. Queries regarding the HRS and the EBF should be directed by e-mail to hrsquest@umich.edu. 
Bibliography

Ballantyne, Harry C., "Present Policies and Methods Regarding the Long-Term Adjustment of Benefits", Social Security Bulletin, 47(10), October 1984.

Board of Trustees of the Federal Old-Age and Survivors Insurance and Disability Insurance Trust Funds: 1995 Annual Report. Washington, D.C.: U.S. Government Printing Office, 1995.

Bondar, Joseph, "How to Compute a Retired-Worker Benefit", Social Security Bulletin, 58(1), Spring 1995. (See also pp. 48-51, Annual Statistical Supplement 1995.)

Fields, Gary S. and Mitchell, Olivia S. Retirement. Pensions and Social Security. Cambridge: MIT Press, 1984.

Gustman, Alan L. and Mitchell, Olivia S. "Pensions and the Labor Market: Behavior and Data Requirements", in Pensions and the U.S. Economy: The Need for Good Data. Ed. Z. Bodie and A. Munnell. Philadelphia, Pa: Pension Research Council and University of Pennsylvania Press, 1992, pp. 39-87.

Gustman, Alan. L. and Steinmeier, Thomas L. "A Structural Retirement Model," Econometrica, May, 1986, 54(3), pp. 555-584.

Gustman, Alan, Olivia S. Mitchell and Thomas Steinmeier. "Retirement Research Using the Health and Retirement Survey". Journal of Human Resources (1995).

Hurd, Michael D. "The Joint Retirement Decision Of Husbands And Wives", in Issues In The Economics of Aging. Ed. D. Wise. Chicago: University of Chicago Press, 1990, pp. 231-254.

Hurd, Michael D. "Research On The Elderly: Economic Status, Retirement, and Consumption and Saving", Journal of Economic Literature, June 1990, 28(2), pp. 565-637.

Leonesio, Michael, "Social Security and Older Workers", Social Security Bulletin, 56(2), Summer 1993.

Lingg, Barbara A., "Women Beneficiaries Aged 62 or Older, 1960-88, Social Security Bulletin, 53(7), July 1990. (For updated data, see Tables 5.A14 and 5.A15 in the Annual Statistical Supplement. $\underline{1995}$ to the Social Security Bulletin).

Mitchell, Olivia S. "Social Security Reforms and Poverty Among Dual-Earner Couples." Journal of Population Economics 4, (1991): 281-293.

Myers, Robert. Social Security. Pension Research Council and University of Pennsylvania Press: Philadelphia, 1993.

Nelson Jr., William J., "Disability Trends in the United States: A National and Regional Perspective", Social Security Bulletin, 57(3), Fall 1994.

Office of the Actuary, Users Guide for PIA Calculation Program, Version 1995.1, Social Security Administration, US Department of Health and Human Services, Publication \#11-11501, 1995.

Pozzebon, Silvana and Mitchell, Olivia S. "Married Women's Retirement Behavior, "Journal of Population Economics, 2(1), 1989. pp. 301-53. 
Quinn, Joseph F., Burlkhauser, Richard V., and Myers, Daniel A. Passing The Torch: The Influence of Economic Incentives on Work and Retirement. Kalamazoo: W.E. Upjohn Institute, 1990.

Social Security Administration (SSA), Annual Statistical Supplement to the Social Security Bulletin, US Department of Health and Human Services, Social Security Administration, various years.

"Social Security Programs in the United States", Social Security Bulletin, 56(4), Winter 1993.

Steuerle, C. Eugene and Jon M. Bakija, Retooling Social Security for the 21st Century, The Urban Institute, 1994.

Thompson, Lawrence H. "The Social Security Reform Debate", Journal of Economic Literature, December 1983, 21(4), pp. 1.425-1467.

US Department of Health and Human Services, SSA's Retirement History Survey: Complation of Reports, September 1987. 
Table 1. Descriptive Statistics on EBF Covered Employment Variables Mean Std. Dev.

I. Fraction of years by decade with zero reported earnings (\%)

Married Men

Age 20-29

15.43

24.80

Age 30-39

10.16

24.84

Age 40-49

12.44

27.63

Age 50-59

12.06

25.66

Married Women

Age 20-29

52.44

33.12

Age 30-39

52.96

37.61

Age 40-49

39.42

39.85

Age 50-59

28.68

34.60

Nonmarried men

Age 20-29

15.62

24.99

Age 30-39

13.91

27.58

Age 40-49

20.88

33.14

Age 50-59

20.53

32.14

Nonmarried women

Age 20-29

47.67

34.71

Age 30-39

39.95

37.41

Age 40-49

29.30

37.39

Age 50-59

20.33

31.29

II. Work in Covered Employment Married Men

Total QC's (\#)

QC 1982-83(\#)

125.00

34.90

QC 1984-85(\#)

7.40

2.73

QC 1986-87(\#)

6.90

2.78

QC 1988-89(\#)

6.71

2.78

6.69

2.79

QC 1990-91(\#)

6.60

32.85

Yrs. Cov. Employment

26.20

6.37

Married Women

Total QC's (\#)

QC 1982-83(\#)

QC 1984-85(\#)

QC 1986-87(\#)

QC 1988-89(\#)

QC 1990-91(\#)

71.65

4.50

4.62

4.78

4.81

4.72

41.88

3.78

3.71

3.70

3.70

Yrs. Cov. Employment

Age 20-50

15.52

8.48

Nonmarried Men

Total QC's (\#)

QC 1982-83(\#)

114.71

38.42

QC 1984-85(\#)

5.83

3.32

5.90

3.36

QC 1986-87(\#)

5.90

3.29

QC 1988-89(\#)

5.79

3.37

QC 1990-91(\#)

5.75

3.38

Yrs. Cov. Employment

Age 20-50

24.96

6.95 
Table 1 (cont.)

Mean Std. Dev.

\section{Nonmarried Women}

Total QC's (\#)

QC 1982-83(\#)

QC 1984-85(\#)

QC 1986-87(\#)

QC 1988-89(\#)

QC 1990-91(\#)

Yrs. Cov. Employment

Age 20-50

85.11

5.40

5.48

5.64

5.76

5.74

44.43

3.55

3.49

3.46

3.38

3.41

C. Disability Insured as of $12 / 91(\%)$

Married Men

84

Married Women

59

Nonmarried Men

75

Nonmarried Women

72

Note: Number of observations reported as Sample 2 in Appendix D. All tabulations weighted by HRS sample weights. 
Table 2. Descriptive Statistics on Earnings Variables in the EBF Mean Std. Dev.

I. Average Annual Real Taxable Earnings by Decade of Life (\$) Married Men

Age 20-29

14544

5974

Age 30-39

23929

9280

Age 40-49

28823

14095

Age 50-59

27692

18084

Married Women

Age 20-29

6566

7407

Age 40-49

10484

5412

10578

7625

10145

Age 50-59

Nonmarried Men

Age 20-29

12551

12170

Age 30-39

20538

6334

Age 40-49

22070

10282

20476

14755

Age 50-59

Age 20-29

6450

17869

Age 30-39

9613

5556

13511

8532

Age 40-49

14692

11491

Age 50-59

13639

II. Average Indexed Monthly Earnings (\$)

Married Men

1992

858

Married Women

641

585

Nonmarried Men

1567

895

Nonmarried Women

838

703

Note: Number of observations reported as Sample 2 in Appendix D. In Panel I earnings are included only up to the Social Security taxable maximum earnings and averages computed only over those with at least one nonzero earnings year using years over which there were positive earnings. For the group age 50-59, average earnings are computed only over relevant years. In Panel II zero years of earnings are included in AIME formula as relevant; see text. 
Table 3. Descriptive Statistics on Social Security Variables in the EBF

$$
\text { Mean Std. Dev. }
$$

I. Respondent's Average Primary Insurance Amount (1992\$)

\section{Married Men}

Based on

Earnings through $1991 \quad 808 \quad 277$

Earnings to early ret. age $\quad 866 \quad 295$

Earnings to normal ret. age $\quad 882 \quad 304$

Married Women

Based on

Earnings through 1991

Earnings to early ret age

Earnings to normal ret. age $\quad 423 \quad 316$

Nonmarried Men

Based on

Based on earnings through $1991 \quad 677 \quad 306$

Earnings to early ret. age $\quad 732 \quad 335$

Earnings to normal ret. age $\quad 754 \quad 347$

Nonmarried Women

Based on

Based on earnings through $1991 \quad 419 \quad 291$

Earnings to early ret. age $\quad 487 \quad 320$

Earnings to normal ret. age $\quad 518 \quad 337$

II. Social Security Wealth Forecasts (Present value, 1992\$)

Married Men (Couple's benefits)

As of 1992

47263

As of early ret. age $\quad 161641 \quad 47559$

As of normal ret. age $\quad 175457 \quad 50818$

Married Women (Couple's benefits)

As of 1992

51001

As of early ret. age $\quad 170994 \quad 50003$

As of normal ret. age $\quad 187650 \quad 55284$

Nonmarried Men*

Current $\quad 67777 \quad 31436$

As of early ret. age $\quad 72942 \quad 33383$

As of normal ret. age $\quad 75761 \quad 34643$

Nonmarried Women*
As of 1992

As of early ret. age $\quad 58474 \quad 38265$

As of normal ret. age $\quad 64644$ 
Table 3 (cont.) Mean Std, Dev.

B. Components of Social Security Wealth Forecasts for Married Couples

(Present value, 1992\$)

Married Men

Based on Earnings Through 1991

Respondent's own $\quad 80804 \quad 30351$

Respondent's spouse $\quad 486 \quad 3268$

Respondent's surv. sps. $\quad 902 \quad 3197$

Spouse's own $\quad 19258 \quad 26207$

Spouse's spouse $\quad 14709 \quad 15776$

Spouse's surv. sps. $\quad 32039 \quad 14602$

Based on Earnings To Early Retirement Age

Respondent's own $\quad 85832 \quad 31275$

Respondent's spouse $\quad 646 \quad 3897$

Respondent's surv. sps. $\quad 1383 \quad 3936$

Spouse's own $\quad 26507 \quad 31511$

Spouse's spouse $\quad 14197 \quad 16696$

Spouse's surv. sps. $\quad 33077 \quad 16435$

Based on Earnings To Normal Retirement Age

Respondent's own $\quad 88808 \quad 32346$

Respondent's spouse $\quad 729 \quad 4242$

Respondent's surv. sps. $\quad 1852 \quad 5144$

Spouse's own $\quad 27854 \quad 34906$

Spouse's spouse $\quad 14923 \quad 17419$

Spouse's surv. sps. $\quad 41291 \quad 21566$

Married Women

Based on Earnings Through 1991

Respondent's own $\quad 22535 \quad 28754$

Respondent's spouse $\quad 16344 \quad 16803$

Respondent's surv. sps. $\quad 34719 \quad 17723$

Spouse's own $\quad 86565 \quad 33902$

Spouse's spouse $\quad 682 \quad 3896$

Spouse's surv. sps. $\quad 936 \quad 3033$

Based on Earnings To Early Retirement Age

Respondent's own $\quad 27373 \quad 32588$

Respondent's spouse $\quad 15941 \quad 17513$

Respondent's surv. sps. $\quad 35757 \quad 18372$

Spouse's own $\quad 89923 \quad 33693$

Spouse's spouse $\quad 778 \quad 4311$

Spouse's surv. sps. $\quad 1220 \quad 3626$

Based on Earnings To Normal Retirement Age

Respondent's own $\quad 28613 \quad 35933$

Respondent's spouse $\quad 16931 \quad 18194$

Respondent's surv. sps. $\quad 43451 \quad 22374$

Spouse's own $\quad 96150 \quad 37963$

Spouse's spouse $\quad 785 \quad 4276$

Spouse's surv. sps. $\quad 1721 \quad 4914$

Note: Number of observations reported as Sample 3 in Appendix D.

*Wealth values for nonmarried persons are based on respondent's own earnings records, and underestimate benefits available as survivors (for widows/ers) and divorced spouses (if the marriage lasted 10 years prior to divorce); see text. 
Table 4. Wage and Inflation Projections

\begin{tabular}{|c|c|c|}
\hline & Projected Ar & anges in \\
\hline & Average Annual & Consumer \\
\hline & Wage in Covered & Price \\
\hline Year & Employment & Index \\
\hline$\overline{1993}$ & $1.3 \%$ & 2.8 \\
\hline 1994 & 3.5 & 2.5 \\
\hline 1995 & 4.0 & 3.1 \\
\hline 1996 & 4.1 & 3.2 \\
\hline 1997 & 4.3 & 3.3 \\
\hline 1998 & 4.1 & 3.4 \\
\hline 1999 & 4.2 & 3.5 \\
\hline 2000 & 4.5 & 3.7 \\
\hline 2001 & 4.7 & 3.9 \\
\hline 2002 & 4.8 & 4.0 \\
\hline 2003 & 4.9 & 4.0 \\
\hline 2004-2010 & 5.1 & 4.0 \\
\hline $2011+$ & 5.0 & 4.0 \\
\hline
\end{tabular}

Source: Board of Trustees (1995), Table П. D1. 
Table 5. Longevity Patterns Over Time

\begin{tabular}{cccccccccc} 
& \multicolumn{10}{c}{} & \multicolumn{8}{c}{ Birth Cohort } \\
& $\underline{1900}$ & $\underline{1910}$ & $\underline{1920}$ & $\underline{1930}$ & $\underline{1940}$ & $\underline{1950}$ & $\underline{1960}$ & $\underline{1970}$ & $\underline{1980}$ \\
$\begin{array}{c}\text { Life Expectancies } \\
\text { At birth: Men }\end{array}$ & 52.0 & 56.7 & 62.3 & 66.6 & 69.7 & 72.3 & 73.4 & 74.8 & 76.2 \\
Women & 58.8 & 64.4 & 70.2 & 73.9 & 76.8 & 79.4 & 80.4 & 81.7 & 82.9 \\
& & & & & & & & & \\
At age 25: Men & 68.8 & 70.7 & 72.8 & 74.4 & 75.8 & 76.6 & 77.1 & 77.8 & 78.4 \\
Women & 75.1 & 77.8 & 79.5 & 80.6 & 81.6 & 82.5 & 83.2 & 83.8 & 84.4 \\
& & & & & & & & & \\
At age 65: Men & 79.0 & 79.8 & 80.8 & 81.4 & 81.9 & 82.3 & 82.8 & 83.2 & 83.6 \\
Women & 83.5 & 84.4 & 84.9 & 85.4 & 85.8 & 86.2 & 86.7 & 87.1 & 87.5 \\
& & & & & & & & & \\
Survival Rates & & & & & & & & & \\
Birth to 65: Men & 46.7 & 52.4 & 60.2 & 66.8 & 72.2 & 75.6 & 77.1 & 79.0 & 80.7 \\
Women & 57.8 & 65.3 & 72.7 & 77.7 & 81.5 & 84.6 & 85.9 & 87.2 & 88.4 \\
Birth to 85: Men & 11.0 & 14.1 & 18.6 & 22.3 & 25.6 & 28.3 & 30.3 & 32.5 & 34.6 \\
Women & 25.5 & 31.3 & 36.7 & 40.5 & 43.8 & 47.0 & 49.1 & 51.2 & 53.1 \\
Birth to 100:Men & 0.2 & 0.3 & 0.5 & 0.7 & 1.0 & 1.3 & 1.7 & 2.0 & 2.5 \\
Women & 1.3 & 1.8 & 2.5 & 3.2 & 4.1 & 5.1 & 6.0 & 7.1 & 8.2
\end{tabular}

Source: Computed by authors using data supplied by the Office of the Actuary, Social Security Administration. 


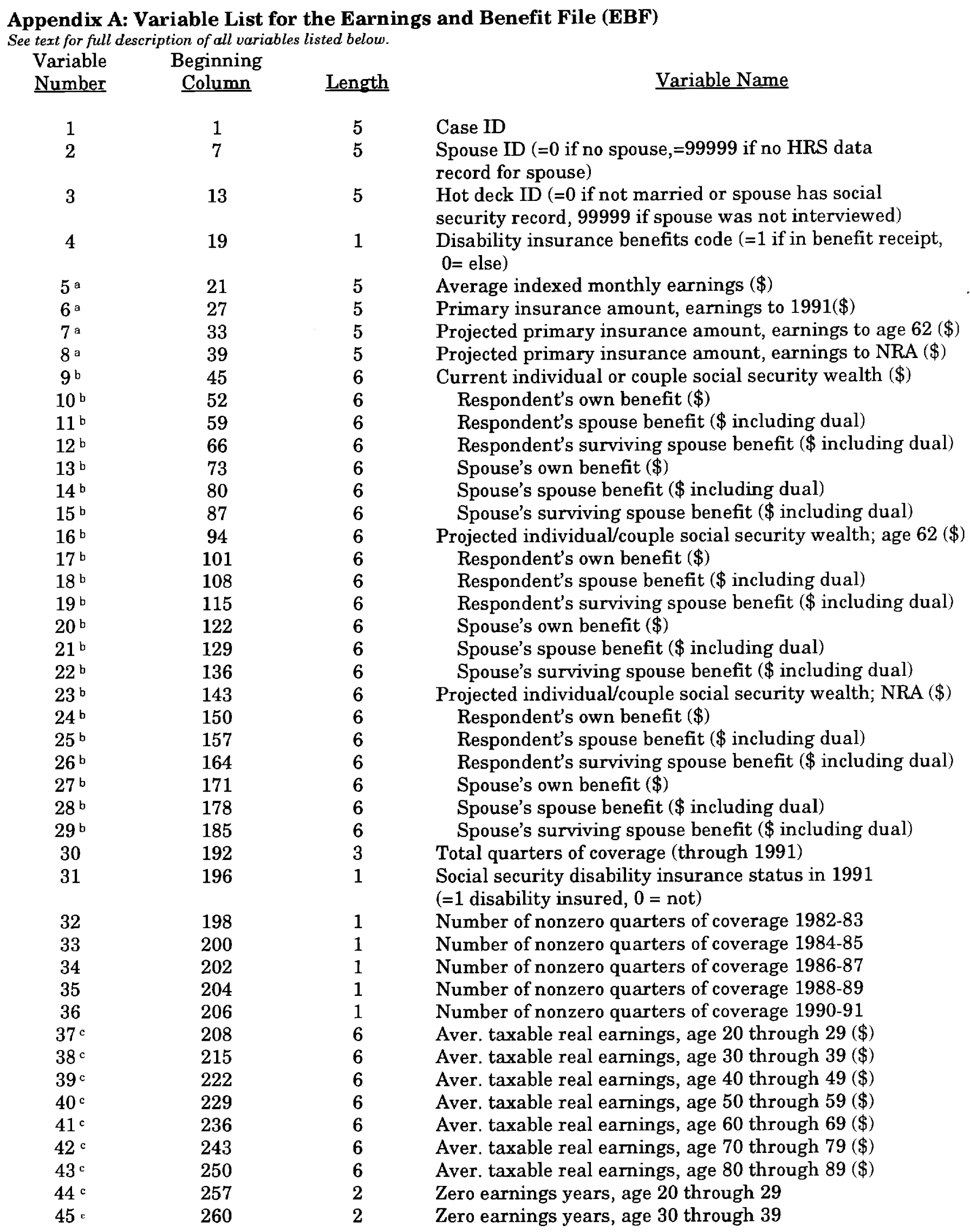




$\begin{array}{cccc}46 \text { c } & 263 & 2 & \text { Zero earnings years, age } 40 \text { through } 49 \\ 47 \text { c } & 266 & 2 & \text { Zero earnings years, age 50 through } 59 \\ 48 \text { c } & 269 & 2 & \text { Zero earnings years, age } 60 \text { through } 69 \\ 49 \text { c } & 272 & 2 & \text { Zero earnings years, age 70 through } 79 \\ 50 \text {. } & 275 & 2 & \text { Zero earnings years, age } 80 \text { through } 89 \\ 51 \text { d } & 278 & 6 & \text { Lowest earnings year in AIME average } \\ 52^{\mathrm{d}} & 285 & 6 & \text { Next lowest earnings year in AIME average } \\ 53 \mathrm{~d} & 292 & 6 & \text { Third lowest earnings year in AIME average } \\ \ldots & \ldots & \ldots & \text {... } \\ 70 \text { d } & 411 & 6 & \text { 20th lowest earnings year in AIME average }\end{array}$

Note: Respondents who declined permission to link HRS and administrative records have no EBF record; see text. Variables 5-8 rounded to nearest $\$ 10$ and variables 37-43 are rounded to nearest $\$ 100$. Variables 9-29 hotdecked as required; cf Sect. II.F a Values based on respondent's own earnings record; equal to 0 if none, or -9 if worker (or spouse) receiving DI in 1991.

b Includes earnings only to maximum social security taxable earnings. Equal to $\mathbf{- 9}$ if the respondent (or spouse) receiving DI in 1991. Equal to 0 if respondent not eligible for benefits or eligibility is unknown (e.g. for current widows). Equal to 0 for spouse benefits where spouse could not be interviewed in the HRS.

E Excludes years before 1951 and after 1991.

d Equal to -9 if respondent receiving DI. 


\section{Appendix B. Descriptive Linear Regression Models for Selected EBF Constructed Employment and Earnings Variables}

(NB: Variable definitions appear in note at end of table)

Married Men $(\mathrm{N}=2186)$

I. Dep. Var. AIME

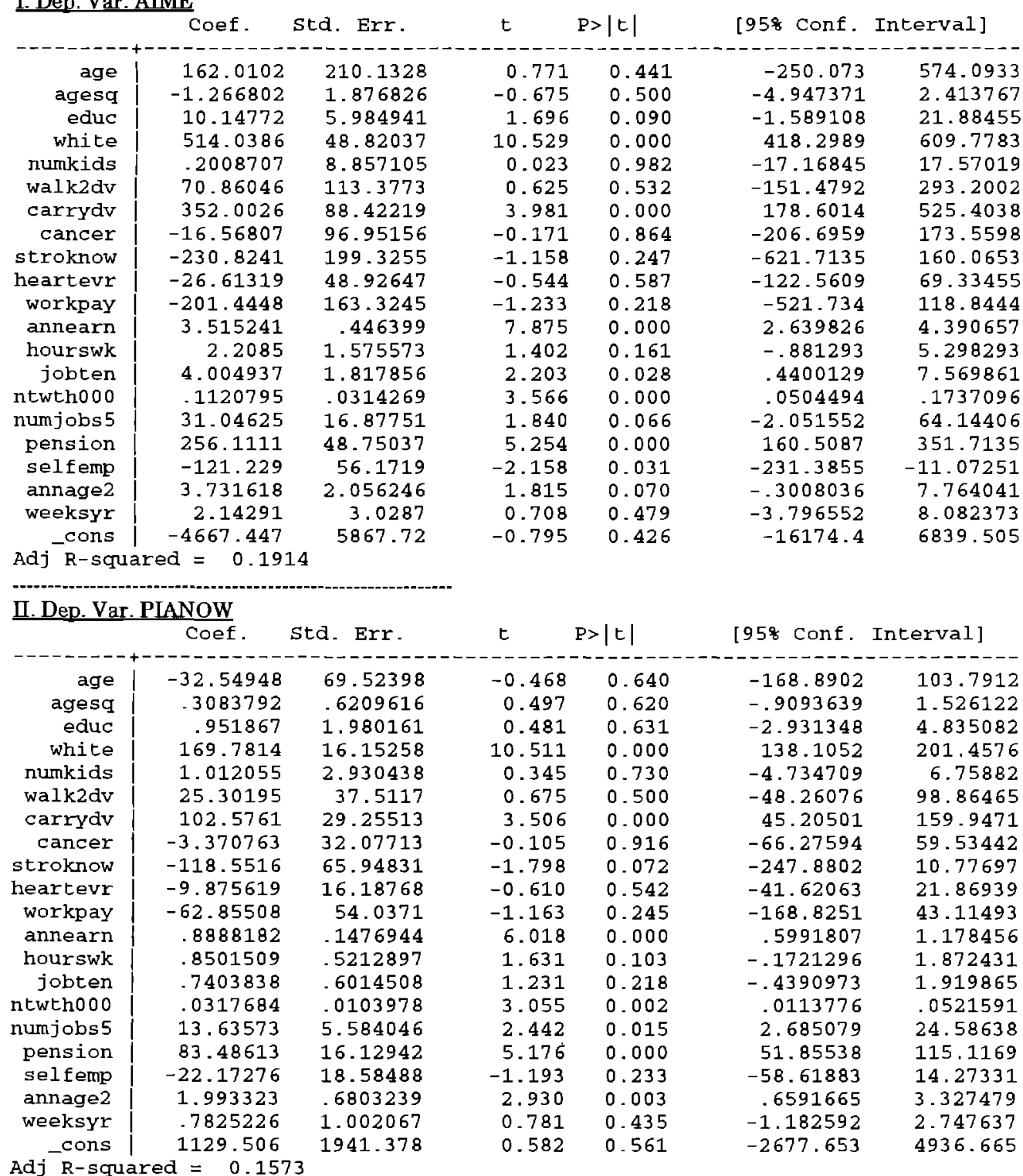


Married Men (cont.)

III. Dep Var PIAER

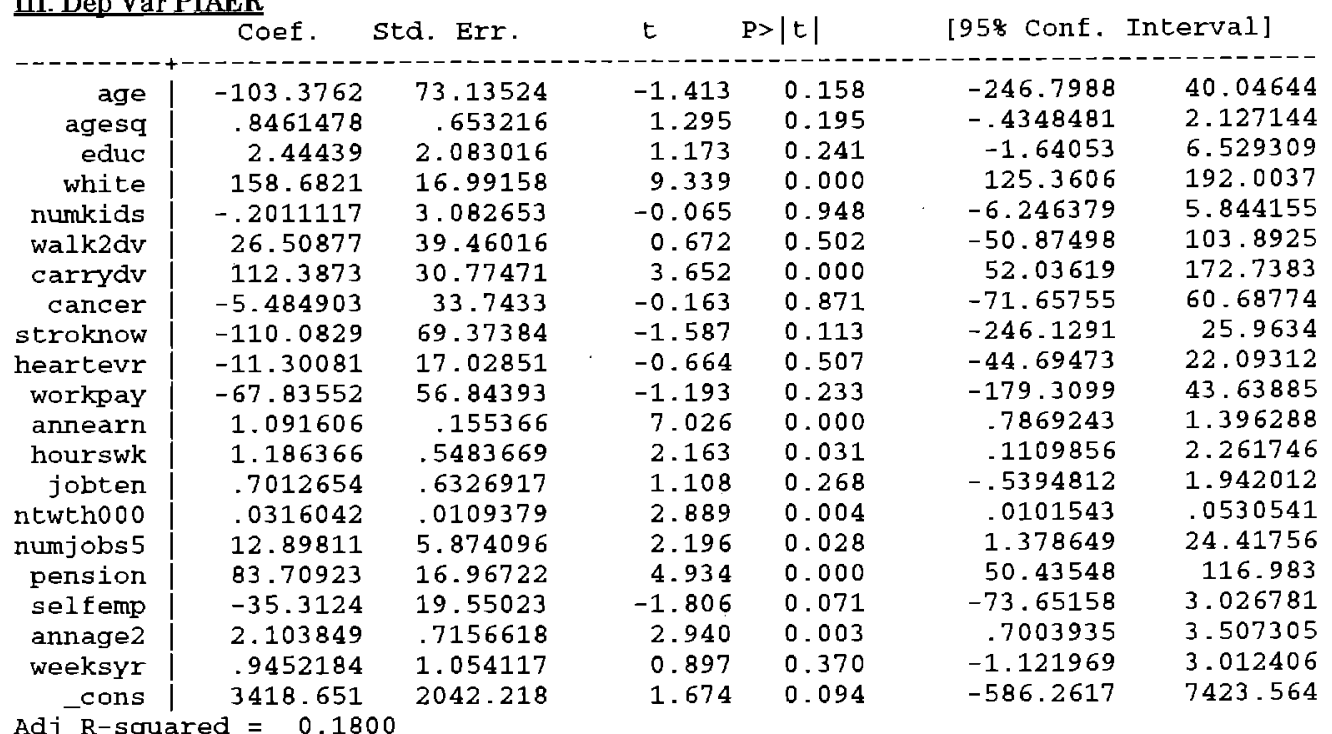

\begin{tabular}{|c|c|c|c|c|c|c|}
\hline \multicolumn{6}{|c|}{ IV. Dep.Var. PIANR } & Interval] \\
\hline age & -182.15 & 74.74326 & -2.437 & 0.015 & -328.7261 & -35.57398 \\
\hline agesq & 1.522968 & .6675783 & 2.281 & 0.023 & .2138064 & 2.832129 \\
\hline educ & 3.444232 & 2.128815 & 1.618 & 0.106 & -.730503 & 7.618967 \\
\hline white & 147.6575 & 17.36518 & 8.503 & 0.000 & 113.6034 & 181.7117 \\
\hline numkids & -.7899623 & 3.150431 & -0.251 & 0.802 & -6.968147 & 5.388222 \\
\hline walk $2 d v$ & 25.8542 & 40.32777 & 0.641 & 0.522 & -53.23099 & 104.9394 \\
\hline carrydv & 117.5303 & 31.45136 & 3.737 & 0.000 & 55.85232 & 179.2083 \\
\hline cancer & -4.778592 & 34.48522 & -0.139 & 0.890 & -72.40617 & 62.84899 \\
\hline stroknow & -106.468 & 70.89916 & -1.502 & 0.133 & -245.5055 & 32.5695 \\
\hline heartevr & -12.74492 & 17.40291 & -0.732 & 0.464 & -46.87308 & 21.38324 \\
\hline workpay & -81.75767 & 58.09376 & -1.407 & 0.159 & -195.683 & 32.1677 \\
\hline annearn & 1.218338 & .158782 & 7.673 & 0.000 & .906957 & 1.529719 \\
\hline hourswk & 1.330471 & .5604238 & 2.374 & 0.018 & 2314464 & 2.429496 \\
\hline jobten & .6737857 & .6466027 & 1.042 & 0.298 & -.5942412 & 1.941813 \\
\hline ntwtho00 & .0317527 & .0111784 & 2.841 & 0.005 & .0098311 & .0536742 \\
\hline numjobs 5 & 12.54496 & 6.00325 & 2.090 & 0.037 & .7722257 & 24.31769 \\
\hline pension & 84.91433 & 17.34028 & 4.897 & 0.000 & 50.909 & 118.9197 \\
\hline selfemp & -39.61422 & 19.98008 & -1.983 & 0.048 & -78.79636 & -.4320765 \\
\hline annage 2 & 2.10083 & .7313971 & 2.872 & 0.004 & .6665166 & 3.535144 \\
\hline weeksyr & 1.297082 & 1.077294 & 1.204 & 0.229 & -8155573 & 3.409721 \\
\hline$=0 \mathrm{Nay}$ & 5709.484 & 2087.12 & 2.736 & 0.006 & 1616.515 & 9802.453 \\
\hline
\end{tabular}


Married Men (cont.)

V. Dep. Var. Worklt50

\begin{tabular}{|c|c|c|c|c|c|c|}
\hline 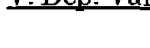 & Coef. & std. Err. & $t$ & $P>|t|$ & {$\left[\begin{array}{lll}958 & \text { Conf }\end{array}\right.$} & Interval] \\
\hline age & 1.655217 & 1.629063 & 1.016 & 0.310 & -1.539473 & 4.849907 \\
\hline agesq & -.0169917 & .0145502 & -1.168 & 0.243 & -.0455255 & 011542 \\
\hline educ & -.2043534 & .0463985 & -4.404 & 0.000 & -.2953436 & -.1133631 \\
\hline white & 4.256968 & .3784818 & 11.247 & 0.000 & 3.514743 & 4.999194 \\
\hline numkids & .0674527 & .068665 & 0.982 & 0.326 & -.0672036 & .202109 \\
\hline walk $2 \mathrm{dv}$ & -.0685121 & .8789618 & -0.078 & 0.938 & -1.792209 & 1.655185 \\
\hline carrydu & 1.274463 & .6854964 & 1.859 & 0.063 & -.0698367 & 2.618763 \\
\hline cancer & .0716281 & .7516206 & 0.095 & 0.924 & -1.402345 & 1. 545601 \\
\hline stroknow & -1.681668 & 1.545279 & -1.088 & 0.277 & -4.712053 & 1.348717 \\
\hline heartevr & -.007997 & .3793043 & -0.021 & 0.983 & -.7518355 & .7358415 \\
\hline workpay & .7027019 & 1. 266179 & 0.555 & 0.579 & -1.780352 & 3.185756 \\
\hline annearn & .0024512 & .0034607 & 0.708 & 0.479 & -.0043355 & .0092379 \\
\hline hourswk & .0158606 & .0122147 & 1.298 & 0.194 & -.0080931 & .0398143 \\
\hline jobten & .0242441 & .014093 & 1.720 & 0.086 & -.0033931 & .0518813 \\
\hline ntwth000 & .000394 & .0002436 & 1.617 & 0.106 & -.0000838 & .0008718 \\
\hline numjobs5 & .4841964 & .1308435 & 3.701 & 0.000 & .2276044 & .7407884 \\
\hline pension & .8633358 & .3779391 & 2.284 & 0.022 & .1221744 & 1.604497 \\
\hline selfemp & -.3605491 & .4354748 & -0.828 & 0.408 & -1.214541 & .4934432 \\
\hline arnage 2 & .0773521 & .0159411 & 4.852 & 0.000 & .0460906 & .1086136 \\
\hline weeksyr & -.0144786 & .0234801 & -0.617 & 0.538 & -.0605245 & .0315673 \\
\hline _cons & -22.60566 & 45.48972 & -0.497 & 0.619 & -111.8137 & 66.60241 \\
\hline
\end{tabular}

Adj R-squared $=0.1058$

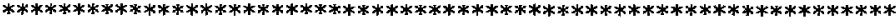

Married Women ( $\mathrm{N}=2089$ )

I. Dep. Var. AIME

\begin{tabular}{|c|c|c|c|c|c|c|}
\hline-1 & Coef. & d. Err. & $t$ & $|t|$ & {$[95 \%$ Conf. } & iterval] \\
\hline age & 124.0917 & 132.2124 & 0.939 & 0.348 & -135.1916 & 383.3749 \\
\hline agesq & -.9777382 & 1.180697 & -0.828 & 0.408 & -3.293218 & 1.337741 \\
\hline educ & 15.81753 & 4.639884 & 3.409 & 0.001 & 6.718199 & 24.91686 \\
\hline white & -22.71313 & 32.21558 & -0.705 & 0.481 & -85.89147 & 40.46521 \\
\hline numkids & -18.4554 & 5.318291 & -3.470 & 0.001 & -28.88516 & -8.025634 \\
\hline walk $2 d v$ & 83.65422 & 62.20458 & 1.345 & 0.179 & -38.33591 & 205.6444 \\
\hline carrydu & 17.48063 & 32.39892 & 0.540 & 0.590 & -46.05726 & 81.01852 \\
\hline cancer & 38.1801 & 41.08699 & 0.929 & 0.353 & -42.39607 & 118.7563 \\
\hline stroknow & -158.4834 & 134.7127 & -1.176 & 0.240 & -422.6701 & 105.7033 \\
\hline heartevr & 25.37603 & 36.04533 & 0.704 & 0.482 & -45.31289 & 96.06494 \\
\hline workpay & -495.9378 & 88.6042 & -5.597 & 0.000 & -669.7005 & -322.1751 \\
\hline annearn & 13.70094 & .9093184 & 15.067 & 0.000 & 11.91767 & 15.48422 \\
\hline hourswk & 3.870961 & 1.139838 & 3.396 & 0.001 & 1. 635612 & 6.10631 \\
\hline jobten & 9.307789 & 1.612379 & 5.773 & 0.000 & 6.145734 & 12.46984 \\
\hline ntwth 000 & .0229028 & .0187185 & 1.224 & 0.221 & -.0138062 & .0596117 \\
\hline numjobs 5 & 119.277 & 12.52695 & 9.522 & 0.000 & 94.71028 & 143.8438 \\
\hline pension & 123.3738 & 32.56853 & 3.788 & 0.000 & 59.5033 & 187.2443 \\
\hline sel femp & -78.26161 & 43.25042 & -1.809 & 0.071 & -163.0805 & 6.557294 \\
\hline annage 2 & -4.525376 & 1.231398 & -3.675 & 0.000 & -6.940286 & -2.110467 \\
\hline weeksyr & 6.328893 & 1.740316 & 3.637 & 0.000 & 2.915938 & 9.741847 \\
\hline _cons & -3458.492 & 3691.62 & -0.937 & 0.349 & $-10698 \cdot 17$ & 3781.187 \\
\hline
\end{tabular}


Married Women (cont.)

I. Dep. Var. PIANOW

\begin{tabular}{|c|c|c|c|c|c|c|}
\hline & Coef & td. Err. & $t$ & $>|t|$ & $95 \%$ Conf & nterval] \\
\hline & ----1 & 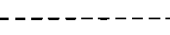 & --- & & ---- & ------ \\
\hline age & -20.79853 & 60.1877 & -0.346 & 0.730 & -138.8333 & 97.23627 \\
\hline agesq & .2345335 & .5374947 & 0.436 & 0.663 & -.8195536 & 1. 288621 \\
\hline educ & 5.033498 & 2.112237 & 2.383 & 0.017 & .8911651 & 9.17583 \\
\hline white & -5.316928 & 14.66565 & -0.363 & 0.717 & -34.07791 & 23.44406 \\
\hline numkids & -8.820378 & 2.421071 & -3.643 & 0.000 & -13.56837 & -4.072386 \\
\hline walk $2 d v$ & 40.64768 & 28.31769 & 1.435 & 0.151 & -14.88649 & 96.18184 \\
\hline carrydv & 10.76333 & 14.74912 & 0.730 & 0.466 & -18.16133 & 39.688 \\
\hline cancer & 25.04407 & 18.70423 & 1.339 & 0.181 & -11.63701 & 61.72516 \\
\hline stroknow & -58.86473 & 61.32594 & -0.960 & 0.337 & -179.1317 & 61.40229 \\
\hline heartevr & -.8386026 & 16.40909 & -0.051 & 0.959 & -33.01866 & 31.34146 \\
\hline workpay & -209.5453 & 40.33572 & -5.195 & 0.000 & -288.6482 & -130.4425 \\
\hline annearn & 5.230994 & .4139535 & 12.637 & 0.000 & 4.419185 & 6.042803 \\
\hline hourswk & 1.612238 & .5188938 & 3.107 & 0.002 & .5946292 & 2.629847 \\
\hline jobten & 3.819965 & .7340112 & 5.204 & 0.000 & 2.380487 & 5.259443 \\
\hline ntwth000 & .0041014 & .0085213 & 0.481 & 0.630 & -.0126098 & .0208126 \\
\hline numjobs 5 & 65.60049 & 5.702706 & 11.503 & 0.000 & 54.41684 & 76.78413 \\
\hline pension & 56.67376 & 14.82633 & 3.823 & 0.000 & 27.59768 & 85.74985 \\
\hline selfemp & -40.79684 & 19.6891 & -2.072 & 0.038 & -79.40937 & -2.184316 \\
\hline annage 2 & -2.128649 & .5605754 & -3.797 & 0.000 & -3.228 & -1.029298 \\
\hline weeksyr & 3.756607 & .7922526 & 4.742 & 0.000 & 2.202911 & 5.310303 \\
\hline _cons & 660.4077 & 1680.554 & 0.393 & 0.694 & -2635.347 & 3956.162 \\
\hline Adj $R-s q$ & ed $=0.35$ & & & & & \\
\hline III. & $\underline{R}$ & & & & & \\
\hline & $\mathrm{CO}$ & std. Err. & $t$ & $P>|t|$ & [958 Conf. & Interval] \\
\hline & & & & & & --- \\
\hline age & -47.25734 & 63.30749 & -0.746 & 0.455 & -171.4104 & 76.89572 \\
\hline agesq & .3997041 & .5653554 & 0.707 & 0.480 & -.709021 & 1.508429 \\
\hline educ & 5.438073 & 2.221723 & 2.448 & 0.014 & 1.081025 & 9.79512 \\
\hline white & -11.46381 & 15.42584 & -0.743 & 0.457 & -41.7156 & 18.78798 \\
\hline numkids & -8.571915 & 2.546566 & -3.366 & 0.001 & -13.56602 & -3.577814 \\
\hline walk $2 d v$ & 45.00403 & 29.78553 & 1.511 & 0.131 & -13.40871 & 103.4168 \\
\hline carrydv & 13.6341 & 15.51363 & 0.879 & 0.380 & -16.78986 & 44.05806 \\
\hline cancer & 24.28951 & 19.67375 & 1.235 & 0.217 & -14.29292 & 62.87194 \\
\hline stroknow & -75.69336 & 64.50473 & -1.173 & 0.241 & -202.1943 & 50.80762 \\
\hline heartevr & .0919847 & 17.25965 & 0.005 & 0.996 & -33.75611 & 33.94008 \\
\hline workpay & -205.3396 & 42.4265 & -4.840 & 0.000 & -288.5427 & -122.1365 \\
\hline annearn & 6.691108 & .4354105 & 15.367 & 0.000 & 5.837219 & 7.544997 \\
\hline hourswk & 1.973456 & .5457904 & 3.616 & 0.000 & .9031003 & 3.043812 \\
\hline jobten & 2.970664 & .7720582 & 3.848 & 0.000 & 1.456571 & 4.484756 \\
\hline ntwtho00 & .0058141 & .008963 & 0.649 & 0.517 & -.0117633 & .0233916 \\
\hline numjobs5 & 61.13551 & 5.998302 & 10.192 & 0.000 & 49.37217 & 72.89886 \\
\hline pension & 72.27498 & 15.59484 & 4.635 & 0.000 & 41.69175 & 102.8582 \\
\hline selfemp & -54.99805 & 20.70967 & -2.656 & 0.008 & -95.61203 & -14.38406 \\
\hline annage2 & -2.082421 & .5896325 & -3.532 & 0.000 & -3.238756 & -.9260857 \\
\hline weeksyr & 4.257598 & .8333186 & 5.109 & 0.000 & 2.623367 & 5.891829 \\
\hline _cons & 1630.228 & 1767.665 & 0.922 & 0.357 & -1836.36 & 5096.815 \\
\hline
\end{tabular}

Tabls630.doc - 7/31/96 
Married Women (cont.)

IV. Dep. Var PIANR

\begin{tabular}{|c|c|c|c|c|c|c|}
\hline & coef & 1. $\operatorname{Err}$ & t & $|t|$ & 95 conf. & Interval] \\
\hline & & & & & & \\
\hline age & -105.4333 & 66.13624 & -1.594 & 0.111 & -235.1338 & 24.26729 \\
\hline agesq & .9042969 & .5906169 & 1.531 & 0.126 & -.2539689 & 2.062563 \\
\hline educ & 5.437022 & 2.320996 & 2.343 & 0.019 & 8852901 & 9.988755 \\
\hline white & -8.549698 & 16.11511 & -0.531 & 0.596 & -40.15322 & 23.05383 \\
\hline numkids & -6.389294 & 2.660353 & -2.402 & 0.016 & -11.60654 & -1.172044 \\
\hline walk $2 \mathrm{dv}$ & 45.14891 & 31.11642 & 1.451 & 0.147 & -15.87387 & 106.1717 \\
\hline carrydv & 17.01376 & 16.20682 & 1.050 & 0.294 & -14.76962 & 48.79714 \\
\hline cancer & 25.28588 & 20.55283 & 1.230 & 0.219 & -15.02051 & 65.59227 \\
\hline stroknow & -82.29102 & 67.38697 & -1.221 & 0.222 & -214.4444 & 49.86236 \\
\hline heartevr & .0992364 & 18.03085 & 0.006 & 0.996 & -35.26128 & 35.45975 \\
\hline workpay & -205.5064 & 44.32223 & -4.637 & 0.000 & -292.4273 & -118.5856 \\
\hline annearn & 7.404149 & .4548658 & 16.278 & 0.000 & 6.512107 & 8. 296192 \\
\hline hourswk & 2.062817 & .5701777 & 3.618 & 0.000 & .9446344 & 3.180999 \\
\hline jobten & 2.845281 & .8065558 & 3.528 & 0.000 & 1.263535 & 4.427027 \\
\hline ntwth000 & .0068933 & .0093635 & 0.736 & 0.462 & -.0114695 & .0252562 \\
\hline numjobs 5 & 59.75642 & 6.266322 & 9.536 & 0.000 & 47.46746 & 72.04538 \\
\hline pension & 78.39916 & 16.29166 & 4.812 & 0.000 & 46.44939 & 110.3489 \\
\hline sel femp & -62.57791 & 21.63504 & -2.892 & 0.004 & -105.0066 & -20.14919 \\
\hline annage 2 & -2.228476 & .6159788 & -3.618 & 0.000 & -3.43648 & -1.020473 \\
\hline weeksyr & 4.497072 & .8705534 & 5.166 & 0.000 & 2.789819 & 6.204324 \\
\hline cons & 3305.271 & 1846.648 & 1.790 & 0.074 & -316.2125 & 6926.755 \\
\hline
\end{tabular}

Adj $\mathrm{R}$-squared $=0.4405$

\begin{tabular}{|c|c|c|c|c|c|c|}
\hline \\
\hline \multicolumn{3}{|c|}{$\frac{\text { V. Dep Var. Worklt50 }}{\text { Coef . }}$} & $t$ & $P>|t|$ & {$[95 \% \operatorname{conf}$} & Interval] \\
\hline age & -3.032411 & 2.055242 & -1.475 & 0.140 & -7.06297 & .9981484 \\
\hline agesq & .0245526 & .0183539 & 1.338 & 0.181 & -.0114415 & .0605468 \\
\hline educ & -.0588457 & 072127 & -0.816 & 0.415 & -.2002948 & .0826034 \\
\hline white & -.1199997 & .5007912 & -0.240 & 0.811 & -1.102107 & .8621077 \\
\hline numkids & -.3536638 & .0826728 & -4.278 & 0.000 & -.5157945 & -.1915332 \\
\hline walk $2 \mathrm{dv}$ & 1.006885 & .9669703 & 1.041 & 0.298 & -.8894517 & 2.903222 \\
\hline carrydu & -1.11974 & .5036412 & -2.223 & 0.026 & -2.107437 & -.1320433 \\
\hline cancer & 1.576059 & .6386973 & 2.468 & 0.014 & .3235027 & 2.828616 \\
\hline stroknow & -.7423657 & 2.09411 & -0.355 & 0.723 & -4.849149 & 3.364417 \\
\hline heartevr & -.0063204 & 5603247 & -0.011 & 0.991 & -1.10518 & 1.092539 \\
\hline workpay & -3.905222 & 1.377352 & -2.835 & 0.005 & -6.606364 & -1.20408 \\
\hline annearn & .0806679 & .0141354 & 5.707 & 0.000 & .0529469 & .108389 \\
\hline hourswk & .0473267 & 0177188 & 2.671 & 0.008 & .0125782 & .0820752 \\
\hline jobten & .1411983 & .0250644 & 5.633 & 0.000 & .0920441 & .1903524 \\
\hline ntwth000 & -.0005397 & .000291 & -1.855 & 0.064 & -.0011104 & .0000309 \\
\hline numjobs5 & 2.701987 & .1947315 & 13.875 & 0.000 & 2.320097 & 3.083878 \\
\hline pension & .7365246 & .5062778 & 1.455 & 0.146 & -.2563426 & 1.729392 \\
\hline selfemp & -1.720914 & .6723278 & -2.560 & 0.011 & -3.039424 & -.4024044 \\
\hline annage 2 & -.048164 & 0191421 & -2.516 & 0.012 & -.0857038 & -.0106242 \\
\hline weeksyr & .0689475 & .0270532 & 2.549 & 0.011 & .0158932 & .1220019 \\
\hline cons & 108.8546 & 57.38623 & 1.897 & 0.058 & -3.686229 & 221.3954 \\
\hline
\end{tabular}


Nonmarried Men ( $N=405)$

\begin{tabular}{|c|c|c|c|c|c|c|}
\hline \multicolumn{7}{|c|}{ I. Dep. Var. AIME } \\
\hline & Coef & td. Err. & $\mathrm{t}$ & $P>|t|$ & [95\% conf. & Interval] \\
\hline age & 168.4054 & 484.8759 & 0.347 & 0.729 & -784.9385 & 1121.749 \\
\hline agesq & -1.394454 & 4.334342 & -0.322 & 0.748 & -9.916466 & 7.127559 \\
\hline educ & 31.00217 & 13.35372 & 2.322 & 0.021 & 4.7466 & 57.25774 \\
\hline white & 468.396 & 89.89946 & 5.210 & 0.000 & 291.6392 & 645.1528 \\
\hline numkids & 50.69285 & 19.98284 & 2.537 & 0.012 & 11.40338 & 89.98233 \\
\hline walk2dv & -44.74019 & 191.9007 & -0.233 & 0.816 & -422.0479 & 332.5675 \\
\hline carrydv & 327.1591 & 141.1547 & 2.318 & 0.021 & 49.62629 & 604.6919 \\
\hline cancer & -119.3315 & 210.5488 & -0.567 & 0.571 & -533.3044 & 294.6413 \\
\hline stroknow & -366.3083 & 258.1595 & -1.419 & 0.157 & -873.8914 & 141.2747 \\
\hline heartevr & -.5352844 & 106.6608 & -0.005 & 0.996 & -210.2477 & 209.1771 \\
\hline workpay & -640.5215 & 348.3369 & -1.839 & 0.067 & -1325.408 & 44.36485 \\
\hline annearn & 7.964314 & 2.059281 & 3.868 & 0.000 & 3.915436 & 12.01319 \\
\hline hourswk & -1.048988 & 4.209749 & -0.249 & 0.803 & -9.326031 & 7.228055 \\
\hline jobten & 8.243224 & 4.416382 & 1.867 & 0.063 & -.4400943 & 16.92654 \\
\hline ntwth000 & .0311545 & .1437863 & 0.217 & 0.829 & -.2515525 & .3138615 \\
\hline numjobs 5 & 67.48787 & 36.26549 & 1.861 & 0.064 & -3.815918 & 138.7917 \\
\hline pension & 84.34369 & 114.5908 & 0.736 & 0.462 & -140.9603 & 309.6477 \\
\hline selfemp & -43.37646 & 146.2204 & -0.297 & 0.767 & -330.8694 & 244.1165 \\
\hline annage 2 & -4.11432 & 5.048956 & -0.815 & 0.416 & -14.04138 & 5.812739 \\
\hline weeksyr & 16.51517 & 5.961603 & 2.770 & 0.006 & 4.793695 & 28.23664 \\
\hline _cons & -4722.698 & 13533.9 & -0.349 & 0.727 & -31332.52 & 21887.12 \\
\hline Adj R-squ & $d=0.32$ & & & & & \\
\hline II. Dep, V & NOY & & & & & \\
\hline & Coef & std. Err. & t & $P>|t|$ & {$[958 \operatorname{conf}$} & Interval] \\
\hline age & -5.67612 & 168.1614 & -0.034 & 0.973 & -336.3084 & 324.9562 \\
\hline agesq & .0598992 & 1.503207 & 0.040 & 0.968 & -2.895648 & 3.015446 \\
\hline educ & 9.375343 & 4.631249 & 2.024 & 0.044 & .2695635 & 18.48112 \\
\hline white & 143.219 & 31.17833 & 4.594 & 0.000 & 81.91743 & 204.5206 \\
\hline numkids & 18.60784 & 6.930313 & 2.685 & 0.008 & 4.981732 & 32.23395 \\
\hline walk $2 d v$ & -5.863805 & 66.55372 & -0.088 & 0.930 & -136.7191 & 124.9915 \\
\hline carrydv & 145.2386 & 48.95431 & 2.967 & 0.003 & 48.98655 & 241.4907 \\
\hline cancer & -48.77866 & 73.02112 & -0.668 & 0.505 & -192.3499 & 94.79261 \\
\hline stroknow & -180.02 & 89.53312 & -2.011 & 0.045 & -356.0566 & -3.983506 \\
\hline heartevr & 5.509219 & 36.99139 & 0.149 & 0.882 & -67.22181 & 78.24025 \\
\hline workpay & -167.3121 & 120.8078 & -1.385 & 0.167 & -404.8398 & 70.21554 \\
\hline annearn & 2.084716 & .714186 & 2.919 & 0.004 & .6805113 & 3.488921 \\
\hline hourswk & -.8338089 & 1.459997 & -0.571 & 0.568 & -3.704397 & 2.036779 \\
\hline jobten & 2.727672 & 1.53166 & 1.781 & 0.076 & -.2838176 & 5.739162 \\
\hline ntwth 000 & .004382 & .049867 & 0.088 & 0.930 & -.0936646 & .1024285 \\
\hline numjobs 5 & 31.09945 & 12.57735 & 2.473 & 0.014 & 6.370348 & 55.82854 \\
\hline pension & 21.60543 & 39.74161 & 0.544 & 0.587 & -56.53298 & 99.74383 \\
\hline selfemp & -8.985088 & 50.71119 & -0.177 & 0.859 & -108.6914 & 90.72127 \\
\hline annage 2 & -1.078736 & 1.751045 & -0.616 & 0.538 & -4.521572 & 2.3641 \\
\hline weeksyr & 5.396527 & 2.067563 & 2.610 & 0.009 & 1.331366 & 9.461688 \\
\hline _cons & 339.7841 & 4693.735 & 0.072 & 0.942 & -8888.853 & 9568.422 \\
\hline
\end{tabular}


Nonmarried Men (cont.)

III. Dep Var PIAER

\begin{tabular}{|c|c|c|c|c|c|c|}
\hline - & coef. & Std. Err. & $t$ & $P>|t|$ & {$[958$ Conf } & Interval] \\
\hline & & & & & & \\
\hline age & -55.8618 & 178.5183 & -0.313 & 0.755 & -406.8575 & 295.1339 \\
\hline agesq & .4333196 & 1.595789 & 0.272 & 0.786 & -2.704257 & 3.570897 \\
\hline educ & 10.83414 & 4.916484 & 2.204 & 0.028 & 1.167542 & 20.50074 \\
\hline white & 152.3382 & 33.09858 & 4.603 & 0.000 & 87.2611 & 217.4154 \\
\hline numkids & 20.23022 & 7.357147 & 2.750 & 0.006 & 5.764885 & 34.69555 \\
\hline walk $2 \mathrm{dv}$ & -10.14478 & 70.65272 & -0.144 & 0.886 & -149.0594 & 128.7698 \\
\hline carrydu & 143.8895 & 51.96937 & 2.769 & 0.006 & 41.70933 & 246.0696 \\
\hline cancer & -64.73944 & 77.51844 & -0.835 & 0.404 & -217.1532 & 87.67428 \\
\hline stroknow & -197.8792 & 95.04741 & -2.082 & 0.038 & -384.7577 & -11.00074 \\
\hline heartevr & -1.025444 & 39.26967 & -0.026 & 0.979 & -78.23593 & 76.18504 \\
\hline workpay & -163.1097 & 128.2483 & -1.272 & 0.204 & -415.2665 & 89.04716 \\
\hline annearn & 2.586468 & .7581722 & 3.411 & 0.001 & 1.09578 & 4.077157 \\
\hline hourswk & -.7407175 & 1.549917 & -0.478 & 0.633 & -3.788103 & 2.306668 \\
\hline jobten & 2.414327 & 1.625994 & 1.485 & 0.138 & -.7826385 & 5.611292 \\
\hline ntwth000 & -.0055963 & .0529383 & -0.106 & 0.916 & -.1096814 & .0984889 \\
\hline numjobs 5 & 30.38003 & 13.35198 & 2.275 & 0.023 & 4.127882 & 56.63217 \\
\hline pension & 45.04962 & 42.18927 & 1.068 & 0.286 & -37.90128 & 128.0005 \\
\hline sel femp & -24.08313 & 53.83446 & -0.447 & 0.655 & -129.9303 & 81.76407 \\
\hline annage 2 & -.4557673 & 1.85889 & -0.245 & 0.806 & -4.110645 & 3.19911 \\
\hline weeksyr & 5.488807 & 2.194903 & 2.501 & 0.013 & 1.173276 & 9.804339 \\
\hline _cons & 1942.357 & 4982.819 & 0.390 & 0.697 & -7854.666 & 11739.38 \\
\hline
\end{tabular}

Adj R-squared $=0.3470$

\begin{tabular}{|c|c|c|c|c|c|c|}
\hline \multicolumn{7}{|c|}{ IV. Dep.Var. PIANR } \\
\hline & Coef. & ta. Err. & $t$ & $\mathbf{P}>|t|$ & [958 Conf. & Interval] \\
\hline ađa & -1370776 & 1833214 & -0748 & 0455 & $-497 \quad 5169$ & 223.3617 \\
\hline $\begin{array}{r}\text { age } \\
\text { agesg }\end{array}$ & 1.142869 & $\begin{array}{l}183.3214 \\
1.638723\end{array}$ & 0.697 & 0.4356 & -2.079125 & 4.364863 \\
\hline educ & 11.61463 & 5.048762 & 2.300 & 0.022 & 1.687949 & 21.54131 \\
\hline white & 149.6319 & 33.9891 & 4.402 & 0.000 & 82.80388 & 216.4599 \\
\hline numkids & 21.7102 & 7.555091 & 2.874 & 0.004 & 6.855672 & 36.56472 \\
\hline walk $2 d v$ & -10.91138 & 72.55363 & -0.150 & 0.881 & -153.5635 & 131.7407 \\
\hline carrydv & 142.6288 & 53.36761 & 2.673 & 0.008 & 37.69947 & $247-5581$ \\
\hline cancer & -74.65942 & 79.60408 & -0.938 & 0.349 & -231.1738 & 81.85501 \\
\hline stroknow & -204.8773 & 97.60466 & -2.099 & 0.036 & -396.7837 & -12.97078 \\
\hline heartevr & -.1978544 & 40.32622 & -0.005 & 0.996 & -79.48569 & 79.08999 \\
\hline workpay & -162.9904 & 131.6988 & -1.238 & 0.217 & -421.9315 & 95.95075 \\
\hline annearn & 2.814475 & .7785709 & 3.615 & 0.000 & 1.283679 & 4.345271 \\
\hline hourswk & -.6325145 & 1.591617 & -0.397 & 0.691 & -3.76189 & 2.496861 \\
\hline jobten & 2.363908 & 1.669741 & 1.416 & 0.158 & -.9190718 & 5.646888 \\
\hline ntwtho0o & -.0064935 & .0543626 & -0.119 & 0.905 & -.113379 & .1003921 \\
\hline numjobs5 & 30.40801 & 13.71122 & 2.218 & 0.027 & 3.449547 & 57.36647 \\
\hline pension & 52.74275 & 43.32438 & 1.217 & 0.224 & -32.43995 & 137.9254 \\
\hline selfemp & -31.19088 & 55.28288 & -0.564 & 0.573 & -139.8859 & 77.50414 \\
\hline annage $\overline{2}$ & -.3341824 & 1.908904 & -0.175 & 0.861 & -4.087395 & 3.41903 \\
\hline weeksyr & 5.570112 & 2.253957 & 2.471 & 0.014 & 1.138471 & 10.00175 \\
\hline _cons & 4250.428 & 5116.882 & 0.831 & 0.407 & -5810.184 & 14311.04 \\
\hline
\end{tabular}


Nonmarried Men (cont.)

V. Dep. Var. Worklt50

\begin{tabular}{r|rrrrrr}
\hline & Coef. & Std. Err. & $t$ & P $|t|$ & [958 Conf. Interval] \\
age & 3.85613 & 4.252192 & 0.907 & 0.365 & -4.504364 & 12.21662 \\
agesq & -.0365825 & .0380107 & -0.962 & 0.336 & -.1113176 & .0381526 \\
educ & -.1472497 & .1171075 & -1.257 & 0.209 & -.3775019 & .0830025 \\
white & 2.73422 & .7883869 & 3.468 & 0.001 & 1.184125 & 4.284316 \\
numkids & .1845048 & .1752425 & 1.053 & 0.293 & -.1600502 & -5290599 \\
walk2dv & .2901705 & 1.682903 & 0.172 & 0.863 & -3.018687 & 3.599028 \\
carrydv & 3.464239 & 1.237877 & 2.799 & 0.005 & 1.030373 & 5.898105 \\
cancer & -1.148745 & 1.84644 & -0.622 & 0.534 & -4.779143 & 2.481652 \\
stroknow & -5.640705 & 2.263968 & -2.492 & 0.013 & -10.09203 & -1.189379 \\
heartevr & .6793956 & .9353784 & 0.726 & 0.468 & -1.159709 & 2.5185 \\
workpay & -1.494179 & 3.054793 & -0.489 & 0.625 & -7.500393 & 4.512035 \\
annearn & .013858 & .0180592 & 0.767 & 0.443 & -.0216492 & .0493653 \\
hourswk & -.02192 & .036918 & -0.594 & 0.553 & -.0945068 & .0506668 \\
jobten & .0263977 & .0387301 & 0.682 & 0.496 & -.049752 & .1025474 \\
ntwthoo0 & -.0003774 & .001261 & -0.299 & 0.765 & -.0028566 & .0021019 \\
numjobs5 & .6765597 & .3180357 & 2.127 & 0.034 & .0512504 & 1.301869 \\
pension & -.2573915 & 1.004921 & -0.256 & 0.798 & -2.233229 & 1.718446 \\
selfernp & -.2088744 & 1.282302 & -0.163 & 0.871 & -2.730087 & 2.312338 \\
annage2 & -.0026483 & .0442776 & -0.060 & 0.952 & -.0897052 & .0844085 \\
weeksyr & .0775552 & .0522812 & 1.483 & 0.139 & -.025238 & .1803484 \\
- cons & -81.87659 & 118.6876 & -0.690 & 0.491 & -315.2354 & 151.4822
\end{tabular}

Adj $\mathrm{R}$-squared $=0.1376$

Nonmarried Women (N=958)

I. Dep. Var. AIME

Coef. Std. Err $t \quad P>|t|$ [958 Conf. Interval]

\begin{tabular}{|c|c|c|c|c|c|c|}
\hline age & -278.4633 & 227.6947 & -1.223 & 0.222 & -725.314 & 168.3874 \\
\hline agesg & 2.687258 & 2.03406 & 1.321 & 0.187 & -1.304581 & 6.679098 \\
\hline educ & 16.64521 & 7.719616 & 2.156 & 0.031 & 1.495471 & 31.79495 \\
\hline white & 44.148 & 40.15906 & 1.099 & 0.272 & -34.66411 & 122.9601 \\
\hline numkids & -67.47443 & 9.35246 & -7.215 & 0.000 & -85.82862 & -49.12024 \\
\hline walk $2 \mathrm{dv}$ & 73.91702 & 77.11661 & 0.959 & 0.338 & -77.42424 & 225.2583 \\
\hline carrydv & 41.97459 & 50.93704 & 0.824 & 0.410 & -57.98931 & 141.9385 \\
\hline cancer & 48.17743 & 66.47236 & 0.725 & 0.469 & -82.2745 & 178.6294 \\
\hline stroknow & -70.39489 & 174.9704 & -0.402 & 0.688 & -413.7741 & 272.9843 \\
\hline heartevr & 28.39225 & 59.29613 & 0.479 & 0.632 & -87.97634 & 144.7608 \\
\hline workpay & -482.9805 & 198.1334 & -2.438 & 0.015 & -871.8172 & -94.1439 \\
\hline annearn & 13.59088 & 1. 534241 & 8.858 & 0.000 & 10.57994 & 16.60183 \\
\hline hourswk & 1.095975 & 1.934929 & 0.566 & 0.571 & -2.701321 & 4.893271 \\
\hline jobten & 13.62386 & 2.378519 & 5.728 & 0.000 & 8.956017 & 18.2917 \\
\hline ntwth000 & -.033291 & .0958874 & -0.347 & 0.729 & -.22147 & .1548879 \\
\hline numjobs5 & 94.14978 & 18.8694 & 4.990 & 0.000 & 57.11859 & 131.181 \\
\hline pension & 141.6162 & 50.3888 & 2.810 & 0.005 & 42.72823 & 240.5042 \\
\hline selfemp & 177.8137 & 87.07981 & 2.042 & 0.041 & 6.919656 & 348.7077 \\
\hline annage 2 & -3.113207 & 2.43192 & -1.280 & 0.201 & -7.885848 & 1.659434 \\
\hline weeksyr & 7.810638 & 3.888445 & 2.009 & 0.045 & .1795684 & 15.44171 \\
\hline cons & 7587.738 & 6366.699 & 1.192 & 0.234 & -4906.901 & 20082.38 \\
\hline
\end{tabular}


Nonmarried Women (cont.)

II. Dep. Var. PIANOW

\begin{tabular}{|c|c|c|c|c|c|c|}
\hline - & Coef. & std. Err. & $\mathrm{t}$ & $P>|t|$ & [958 Conf. & Interval] \\
\hline & & & & & & \\
\hline age & -168.465 & 95.13677 & -1.771 & 0.077 & -355.1708 & 18.24086 \\
\hline agesg & 1.568706 & .8498829 & 1.846 & 0.065 & -.0991885 & 3.2366 \\
\hline educ & 2.907842 & 3.225456 & 0.902 & 0.368 & -3.422112 & 9.237796 \\
\hline white & 24.29465 & 16.7795 & 1.448 & 0.148 & -8.635096 & 57.2244 \\
\hline numkids & -24.27847 & 3.9077 & -6.213 & 0.000 & -31.94733 & -16.60962 \\
\hline walk2dv & 39.78969 & 32.22132 & 1.235 & 0.217 & -23.44462 & 103.024 \\
\hline carrydv & 24.82156 & 21.28282 & 1.166 & 0.244 & -16.94596 & 66.58907 \\
\hline cancer & 42.92786 & 27.77388 & 1.546 & 0.123 & -11.57834 & 97.43406 \\
\hline stroknow & -21.97503 & 73.10718 & -0.301 & 0.764 & -165.4478 & 121.4977 \\
\hline heartevr & -4.982906 & 24.77546 & -0.201 & 0.841 & -53.60472 & 43.63891 \\
\hline workpay & -161.9883 & 82.78529 & -1.957 & 0.051 & -324.4544 & .4777164 \\
\hline annearn & 4.255469 & .6410456 & 6.638 & 0.000 & 2.997418 & 5.51352 \\
\hline hourswk & .6781848 & .8084636 & 0.839 & 0.402 & -.9084241 & 2.264794 \\
\hline jobten & 4.878727 & .9938069 & 4.909 & 0.000 & 2.928382 & 6.829072 \\
\hline ntwth000 & -.0202183 & .0400642 & -0.505 & 0.614 & -.0988443 & .0584077 \\
\hline numjobs 5 & 50.79038 & 7.884127 & 6.442 & 0.000 & 35.31779 & 66.26297 \\
\hline pension & 68.90581 & 21.05375 & 3.273 & 0.001 & 27.58785 & 110.2238 \\
\hline sel femp & 44.81618 & 36.3842 & 1.232 & 0.218 & -26.58778 & 116.2201 \\
\hline annage 2 & -1.386944 & 1.016119 & -1.365 & 0.173 & -3.381077 & .6071898 \\
\hline weeksyr & 3.765216 & 1.624693 & 2.317 & 0.021 & .5767574 & 6.953675 \\
\hline _cons & 4745.518 & 2660.172 & 1.784 & 0.075 & -475.0665 & 9966.103 \\
\hline
\end{tabular}

Adj $\mathrm{R}$-squared $=0.3932$

III. Dep Var PLAER

$$
\text { Coef. Std. Err. }
$$

$t \quad p>|t|$

$-2.130 \quad 0.033$

$\begin{array}{ll}2.130 & 0.033 \\ 2.105 & 0.036\end{array}$

$\begin{array}{ll}1.268 & 0.205\end{array}$

$1.687 \quad 0.092$

$\begin{array}{ll}-5.205 & 0.000\end{array}$

$\begin{array}{ll}1.086 & 0.278\end{array}$

$1.363 \quad 0.173$

$\begin{array}{ll}1.320 & 0.187\end{array}$

$\begin{array}{ll}-0.113 \quad 0.910 \\ 0.232 & 0.816\end{array}$

$0.232 \quad 0.816$

$-2.253 \quad 0.024$

$9.001 \quad 0.000$

$\begin{array}{ll}1.039 & 0.299\end{array}$

3.8730 .000

$\begin{array}{rl}-0.444 & 0.657\end{array}$

$\begin{array}{ll}5.522 & 0.000\end{array}$

$\begin{array}{ll}2.999 & 0.003\end{array}$

$0.942 \quad 0.347$

$\begin{array}{rl}-1.233 & 0.218\end{array}$

$\begin{array}{ll}1.699384 & 3.005 \\ 2782.467 & 2.232\end{array}$

$\begin{array}{ll}1.699384 & 3.005 \\ 2782.467 & 2.232\end{array}$

$-1.310017$

5.10696

\begin{tabular}{c|c} 
cons & 6210.485 \\
j $\mathrm{R}$-squared $=$ & 0.4502
\end{tabular}

Adj $\mathrm{R}$-squared $=0.4502$

[958 Conf. Interval]

$\begin{array}{rr}-407.2236 & -16.6453 \\ -1269862 & 3.616129 \\ -2.344288 & 10.89763 \\ -4.842223 & 64.04499 \\ -29.29667 & -13.25384 \\ -29.53463 & 102.7481 \\ -13.34431 & 74.03102 \\ -18.6654 & 95.35857 \\ -158.7423 & 141.3948 \\ -44.84041 & 56.87375 \\ -365.0174 & -25.14742 \\ 4.719554 & 7.351328 \\ -.7808709 & 2.538228 \\ 1.986272 & 6.066287 \\ -.1008669 & .0636144 \\ 29.355 & 61.72281 \\ 22.81889 & 109.2538 \\ -38.85539 & 110.5178 \\ -3.395825 & .775792 \\ 1.77192 & 8.442 \\ 749.8971 & 11671.07\end{array}$


Nonmarried Women (cont.)

IV. Dep.Var. PIANR

\begin{tabular}{|c|c|c|c|c|c|c|}
\hline & coef. & std. Err. & $t$ & $P>|t|$ & {$[95 \%$ Conf } & Interval] \\
\hline age & -262.4847 & 103.3997 & -2.539 & 0.011 & -465.4065 & -59.56284 \\
\hline agesq & 2.310397 & .923698 & 2.501 & 0.013 & .4976407 & 4.123153 \\
\hline educ & 4.445204 & 3.505598 & 1.268 & 0.205 & -2.434527 & 11.32494 \\
\hline white & 34.61761 & 18.23685 & 1.898 & 0.058 & -1.172196 & 70.40741 \\
\hline numkids & -19.53077 & 4.247097 & -4.599 & 0.000 & -27.8657 & -11.19585 \\
\hline walk $2 d v$ & 38.04633 & 35.01985 & 1.086 & 0.278 & -30.68009 & 106.7727 \\
\hline carrydv & 32.41049 & 23.1313 & 1.401 & 0.161 & -12.98467 & 77.80565 \\
\hline cancer & 40.54162 & 30.18613 & 1.343 & 0.180 & -18.69863 & 99.78186 \\
\hline stroknow & -3.234158 & 79.45678 & -0.041 & 0.968 & -159.168 & 152.6997 \\
\hline heartevr & 7.760719 & 26.92729 & 0.288 & 0.773 & -45.08406 & 60.6055 \\
\hline workpay & -206.4859 & 89.97546 & -2.295 & 0.022 & -383.0627 & -29.9092 \\
\hline annearn & 6.727449 & .6967225 & 9.656 & 0.000 & 5.360132 & 8.094767 \\
\hline hourswk & 1.101369 & .8786813 & 1.253 & 0.210 & -.6230423 & 2.82578 \\
\hline jobten & 3. 816501 & 1.080122 & 3.533 & 0.000 & 1.696762 & 5.93624 \\
\hline ntwthooo & -.0195642 & .043544 & -0.449 & 0.653 & -.1050192 & .0658908 \\
\hline numjobs 5 & 44.4077 & 8.568889 & 5.182 & 0.000 & 27.59126 & 61.22414 \\
\hline pension & 66.5087 & 22.88234 & 2.907 & 0.004 & 21.60214 & 111.4153 \\
\hline selfemp & 30.66268 & 39.54429 & 0.775 & 0.438 & -46.94295 & 108.2683 \\
\hline annage 2 & -1.358204 & 1.104373 & -1.230 & 0.219 & -3.525534 & .8091265 \\
\hline weeksyr & 5.566279 & 1.765803 & 3.152 & 0.002 & 2.100892 & 9.031666 \\
\hline cons & 7657.787 & 2891.217 & 2.649 & 0.008 & 1983.777 & 13331.8 \\
\hline
\end{tabular}

Adj R-squared $=0.4663$

V.Dep. Var. Worklt50

$\begin{array}{ccrcrr}\text { Coef. } & \text { std. Err. } & \mathrm{t} & \mathrm{P}>|\mathrm{t}| & \text { [958 Conf. Interval] } \\ -6.031014 & 3.045411 & -1.980 & 0.048 & -12.00763 & -.0543974 \\ -052739 & .0272055 & 1.939 & 0.053 & -.0006517 & .1061298 \\ -.0925275 & .1032497 & -0.896 & 0.370 & -.2951548 & .1100999 \\ -.4833166 & .5371264 & -0.900 & 0.368 & -1.537427 & .5707933 \\ -.9167328 & .1250889 & -7.329 & 0.000 & -1.16222 & -.671246 \\ .6916657 & 1.031433 & 0.671 & 0.503 & -1.33252 & 2.715851 \\ .4661079 & .6812816 & 0.684 & 0.494 & -.8709066 & 1.803122 \\ 1.621621 & .889066 & 1.824 & 0.068 & -.1231696 & 3.366413 \\ .2281025 & 2.340225 & -0.097 & 0.922 & -4.820791 & 4.364586 \\ -1.138208 & .7930841 & -1.435 & 0.152 & -2.694634 & .418219 \\ -4.331395 & 2.650029 & -1.634 & 0.102 & -9.532074 & .8692851 \\ .0355501 & .0205204 & 1.732 & 0.084 & -.0047212 & .0758214 \\ -.0112033 & .0258796 & -0.433 & 0.665 & -.0619921 & .0395854 \\ .1737699 & .0318126 & 5.462 & 0.000 & .1113376 & .2362021 \\ .0032436 & .0012825 & -2.529 & 0.012 & -.0057605 & -.0007267 \\ 2.075933 & .2523778 & 8.225 & 0.000 & 1.580642 & 2.571224 \\ 2.088993 & .6739489 & 3.100 & 0.002 & .7663686 & 3.411617 \\ 1.170685 & 1.16469 & 1.005 & 0.315 & -1.115018 & 3.456388 \\ -.0162678 & .0325269 & -0.500 & 0.617 & -.0801017 & .0475662 \\ .1262099 & .0520079 & 2.427 & 0.015 & .0241445 & .2282752 \\ 188.6944 & 85.15443 & 2.216 & 0.027 & 21.57894 & 355.8099\end{array}$

Adj R-squared $=0.2981$

Note: Number of observations reported in Appendix D as Sample 4. All analysis conducted with HRS sample weights; see text. Dependent variables are Average Indexed Monthly Earnings (AIME, var.5), current PIA (PIANOW, var 6), early and normal retirement age PIA (PIAER and PIANR, vars. 7 and 8), and years worked to age 50 (computed by authors using vars. 44-46). All explanatory variables are taken from HRS Wave 1: Age: respondent's age. Agesq: Square of age. Educ.: years of education. White: $1=$ yes, $0=$ no. Numkids: number of own children. Walk2dv: $=1$ can walk 2 blocks readily, $=0$, no. Carrydv: $=1$ can carry 10 lb. weight readily, $=0$ no. Cancer: $=1$ ever had, $=0$ no. Stroknow: $=1$ recent stroke, $=0$ no. Heartnow: $=1$ recent heart trouble, 0 no. Workpay: $=1$ current have paid job $=0$ no. Annearn: annual earnings/1000. Hourswk: Hours of work per week. Jobten: yrs on current job. NetWorth(000): Net worth $/ 1000$. NumJobs $<50$ : No. of jobs held by age 50. Pension: $=1$ have pension, $=0$ no. Selfemp:=1 self employed, 0 no. Annage2: age expects to receive pension (or social security if no pension age). WeeksWork/yr: number of weeks worked/year. 
Appendix C. Descriptive Linear Regression Models for Selected EBF Constructed Social Security Wealth Variables

(NB: Variable definitions appear in note at end of table)

Married Men $(\mathrm{N}=2186)$

I. Dep. Var. Respondent's Own SSW at Normal Retirement

\begin{tabular}{|c|c|c|c|c|c|c|}
\hline & \multicolumn{2}{|c|}{ std. Err. } & \multicolumn{2}{|c|}{$\mathrm{P}>|t|$} & \multicolumn{2}{|c|}{ [95\& conf. Interval] } \\
\hline age & -26475.3 & 8008.824 & -3.306 & 0.001 & -42181.09 & -10769.5 \\
\hline agesq & 250.1029 & 71.53117 & 3.496 & 0.000 & 109.8258 & 390.3799 \\
\hline educ & 3.974589 & 230.8065 & 0.017 & 0.986 & -448.6511 & 456.6003 \\
\hline white & 15577.2 & 1861.703 & 8.367 & 0.000 & 11926.29 & 19228.11 \\
\hline numkids & 161.0844 & 337.9194 & 0.477 & 0.634 & -501.5962 & 823.765 \\
\hline walk2dv & 2807.912 & 4320.717 & 0.650 & 0.516 & -5665.279 & 11281.1 \\
\hline carrydv & 12617.61 & 3370.174 & 3.744 & 0.000 & 6008.496 & 19226.73 \\
\hline cancer & -1446.567 & 3695.553 & -0.391 & 0.696 & -8693.773 & 5800.638 \\
\hline stroknow & -9713.965 & 7600.556 & -1.278 & 0.201 & -24619.12 & 5191.191 \\
\hline heartevr & -767.175 & 1866.509 & -0.411 & 0.681 & -4427.514 & 2893.164 \\
\hline workpay & -240.2068 & 6504.127 & -0.037 & 0.971 & -12995.2 & 12514.78 \\
\hline pay1five & 87.18764 & 23.90533 & 3.647 & 0.000 & 40.30782 & 134.0675 \\
\hline paylast & 222.8958 & 54.57015 & 4.085 & 0.000 & 115.8804 & 329.9112 \\
\hline annearn & 111.0773 & 17.30033 & 6.421 & 0.000 & 77.15026 & 145.0043 \\
\hline hourswk & 147.6985 & 60.05867 & 2.459 & 0.014 & 29.91975 & 265.4772 \\
\hline jobten & 134.4027 & 71.73393 & 1.874 & 0.061 & -6.271937 & 275.0773 \\
\hline ntwth000 & 3. 229469 & 1.199471 & 2.692 & 0.007 & .8772329 & 5.581705 \\
\hline numjobs 5 & 840.0105 & 660.4324 & 1.272 & 0.204 & -455.1378 & 2135.159 \\
\hline pension & 9025.789 & 1860.606 & 4.851 & 0.000 & 5377.027 & 12674.55 \\
\hline selfemp & -4425.026 & 2144.554 & -2.063 & 0.039 & -8630.627 & -219.4251 \\
\hline annage2 & 196.4277 & 78.72237 & 2.495 & 0.013 & 42.04831 & 350.8071 \\
\hline weeksyr & 100.6626 & 115.43 & 0.872 & 0.383 & -125.7026 & 327.0279 \\
\hline _cons & 719272.7 & 223658 & 3.216 & 0.001 & 280665.7 & 1157880 \\
\hline
\end{tabular}

Adj R-squared $=0.1830$

\begin{tabular}{|c|c|c|c|c|c|c|}
\hline & Coef. & std. Err. & $t$ & $\mathrm{P}>|\mathrm{t}|$ & {$[958$ Conf. } & Interval] \\
\hline age & -34476.43 & 12397.43 & -2.781 & 0.005 & -58788.55 & -10164.31 \\
\hline agesq & 331.4868 & 110.7282 & 2.994 & 0.003 & 114.342 & 548.6316 \\
\hline educ & 1349.475 & 357.2819 & 3.777 & 0.000 & 648.8236 & 2050.127 \\
\hline white & 22556.98 & 2881.863 & 7.827 & 0.000 & 16905.47 & 28208.49 \\
\hline nunkids & -808.6741 & 523.0895 & -1.546 & 0.122 & -1834.485 & 217 . 1364 \\
\hline walk $2 \mathrm{dv}$ & 5152.611 & 6688.346 & 0.770 & 0.441 & -7963.645 & 18268.87 \\
\hline carrydv & 20880.48 & 5216.933 & 4.002 & 0.000 & 10649.76 & 31111.21 \\
\hline cancer & 4877.025 & 5720.61 & 0.853 & 0.394 & -6341.441 & 16095.49 \\
\hline stroknow & -10879.87 & 11765.44 & -0.925 & 0.355 & -33952.62 & 12192.88 \\
\hline heartevr & -4117.434 & 2889.303 & -1.425 & 0.154 & -9783.534 & 1548.666 \\
\hline workpay & -10769.08 & 10068.2 & -1.070 & 0.285 & -30513.44 & 8975.281 \\
\hline paylast & 337.9298 & 84.47302 & 4.000 & 0.000 & 172.273 & 503.5865 \\
\hline annearn & 145.4625 & 26.78042 & 5.432 & 0.000 & 92.94449 & 197.9806 \\
\hline hourswk & 106.3313 & 92.96909 & 1. 144 & 0.253 & -75.98676 & 288.6494 \\
\hline paylfive & 104.859 & 37.00477 & 2.834 & 0.005 & 32.29036 & 177.4276 \\
\hline paylast & (aropped) & & & & & \\
\hline jobten & 248.7416 & 111.0421 & 2.240 & 0.025 & 30.98134 & 466.5019 \\
\hline ntwth000 & 6.101021 & 1.856747 & 3.286 & 0.001 & 2.459828 & 9.742215 \\
\hline numjobs5 & 1828.506 & 1022.33 & 1.789 & 0.074 & -176.3463 & 3833.358 \\
\hline pension & 15625.9 & 2880.165 & 5.425 & 0.000 & 9977.724 & 21274.08 \\
\hline selfemp & -5772.775 & 3319.708 & -1.739 & 0.082 & -12282.92 & 737.375 \\
\hline annage 2 & 28.51001 & 121.86 & 0.234 & 0.815 & -210.4648 & 267.4849 \\
\hline weeksyr & 389.8052 & 178.6823 & 2.182 & 0.029 & 39.3983 & 740.2121 \\
\hline _cons & 969124.6 & 346216.1 & 2.799 & 0.005 & 290173.6 & 1648076 \\
\hline
\end{tabular}


Married Women $(\mathrm{N}=2089)$

I. Dep. Var. Respondent's Own SSW at Normal Retirement

\begin{tabular}{|c|c|c|c|c|c|c|}
\hline & Coef & std. Err. & $t$ & $>|t|$ & [958 Conf. & Interval] \\
\hline & & - & & & & \\
\hline age & 451.4093 & 7705.862 & 0.059 & 0.953 & -14660.66 & 15563.47 \\
\hline agesq & -.7629087 & 68.82291 & -0.011 & 0.991 & -135.7324 & 134.2066 \\
\hline educ & 60.13979 & 271.9399 & 0.221 & 0.825 & -473.165 & 593.4446 \\
\hline white & -3484.689 & 1875.033 & -1.858 & 0.063 & -7161.841 & 192.463 \\
\hline numkids & -737.9624 & 309.4729 & -2.385 & 0.017 & -1344.874 & -131.0512 \\
\hline walk $2 d v$ & 3638.617 & 3618.495 & 1.006 & 0.315 & -3457.659 & 10734.8 \\
\hline carrydu & -1354.947 & 1884.832 & -0.719 & 0.472 & -5051.316 & 2341.42 \\
\hline cancer & 1930.906 & 2390.402 & 0.808 & 0.419 & -2756.942 & 6618.7 \\
\hline stroknow & -616.2124 & 7840.773 & -0.079 & 0.937 & -15992.85 & 14760.4 \\
\hline heartevr & 1445.578 & 2097.076 & 0.689 & 0.491 & -2667.024 & 5558.1 \\
\hline workpay & -17580.85 & 5194.305 & -3.385 & 0.001 & -27767.47 & -7394.23 \\
\hline paylfive & 327.0529 & 54.10812 & 6.044 & 0.000 & 220.9408 & 433.165 \\
\hline paylast & 990.9454 & 83.2557 & 11.902 & 0.000 & 827.6715 & 1154.21 \\
\hline annearn & 853.8249 & 53.79409 & 15.872 & 0.000 & 748.3286 & 959.321 \\
\hline hourswk & 346.095 & 66.44474 & 5.209 & 0.000 & 215.7894 & 476.400 \\
\hline jobten & 419.237 & 95.01235 & 4.412 & 0.000 & 232.907 & 605.566 \\
\hline ntwth000 & -.3757034 & 1.089255 & -0.345 & 0.730 & -2.511856 & 1.76044 \\
\hline numjobs 5 & 1811.575 & 787.8264 & 2.299 & 0.022 & 266.5588 & 3356.59 \\
\hline pension & 8070.584 & 1898.69 & 4.251 & 0.000 & 4347.038 & 11794.1 \\
\hline selfemp & -7031.073 & 2517.949 & -2.792 & 0.005 & -11969.06 & -2093.0 \\
\hline annage 2 & -106.605 & 72.19749 & -1.477 & 0.140 & -248.1924 & 34.9824 \\
\hline weeksyr & 338.8934 & 101.2434 & 3.347 & 0.001 & 140.3436 & 537.443 \\
\hline cons & -13001.21 & 215183.8 & -0.060 & 0.952 & -435000.9 & 408998. \\
\hline
\end{tabular}

Adj $\mathrm{R}$-squared $=0.4142$

\begin{tabular}{|c|c|c|c|c|c|c|}
\hline \multicolumn{6}{|c|}{ II. Dep. Var. Couple's SSW at Normal Retirement } & Interval] \\
\hline age & -19142.99 & 14481.99 & -1.322 & 0.186 & -47543.81 & 9257.82 \\
\hline agesq & 201.3328 & 129.3421 & 1.557 & 0.120 & -52.32169 & 454.9874 \\
\hline educ & 1626.678 & 511.0694 & 3.183 & 0.001 & 624.4135 & 2628.943 \\
\hline white & 20933.85 & 3523.838 & 5.941 & 0.000 & 14023.21 & 27844.5 \\
\hline numkids & -30.6216 & 581.6069 & -0.053 & 0.958 & -1171.218 & 1109.975 \\
\hline walk $2 \mathrm{dv}$ & 3550.126 & 6800.407 & 0.522 & 0.602 & -9786.24 & 16886.49 \\
\hline carrydv & 6793.592 & 3542.254 & 1.918 & 0.055 & -153.168 & 13740.35 \\
\hline cancer & -4587.699 & 4492.395 & -1.021 & 0.307 & -13397.79 & 4222.393 \\
\hline stroknow & -23250.29 & 14735.53 & -1.578 & 0.115 & -52148.34 & 5647.75 \\
\hline heartevr & 3572.643 & 3941.133 & 0.907 & 0.365 & -4156.364 & 11301.65 \\
\hline workpay & -13326.38 & 9761.901 & -1.365 & 0.172 & -32470.57 & 5817.813 \\
\hline paylast & 304.0696 & 156.4664 & 1.943 & 0.052 & -2.778596 & 610.9178 \\
\hline annearn & 419.157 & 101.0978 & 4.146 & 0.000 & 220.8929 & 617.4211 \\
\hline hourswk & 29.41773 & 124.8727 & 0.236 & 0.814 & -215.4718 & 274.3072 \\
\hline paylfive & 289.99 & 101.6879 & 2.852 & 0.004 & 90.56852 & 489.4115 \\
\hline paylast & (dropped) & & & & & \\
\hline jobten & 509.2743 & 178.5612 & 2.852 & 0.004 & 159.0957 & 859.453 \\
\hline ntwth000 & 6.681046 & 2.047089 & 3.264 & & 2.666474 & 10.69562 \\
\hline numjobs5 & 1810.451 & 1480.599 & 1.223 & 0.222 & -1093.171 & 4714.073 \\
\hline pension & 7277.839 & 3568.298 & 2.040 & 0.042 & 280.0034 & 14275.67 \\
\hline selfemp & -6163.664 & 4732.101 & -1.303 & 0.193 & -15443.85 & 3116.519 \\
\hline annage 2 & -193.5618 & 135.6841 & -1.427 & 0.154 & -459.6537 & 72.53017 \\
\hline weeksyr & 69.76094 & 190.2715 & 0.367 & 0.714 & -303.383 & 442.9049 \\
\hline cons & 581199.1 & 404405 & 1.437 & 0.151 & -211884.7 & 1374283 \\
\hline
\end{tabular}


Nonmarried Men ( $\mathrm{N}=405)$

Dep. Var. Respondent's Own SSW at Normal Retirement

\begin{tabular}{|c|c|c|c|c|c|c|}
\hline & Coef. & d. Err. & $t$ & $|t|$ & $95 \%$ Conf. & Interval] \\
\hline & 10 & 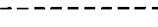 & & & & \\
\hline age & -23261.69 & 17819.2 & -1.305 & 0.193 & -58297.69 & 11774.31 \\
\hline agesq & 215.7932 & 159.282 & 1.355 & 0.176 & -97.38608 & 528.9725 \\
\hline educ & 587.856 & 500.7284 & 1.174 & 0.241 & -396.6728 & 1572.385 \\
\hline white & 11851.87 & 3328.768 & 3.560 & 0.000 & 5306.869 & 18396.87 \\
\hline numkids & 1926.633 & 740.4626 & 2.602 & 0.010 & 470.7402 & 3382.525 \\
\hline walk $2 \mathrm{dv}$ & -5744.29 & 7055.083 & -0.814 & 0.416 & -19615.95 & 8127.368 \\
\hline carrydv & 12442.21 & 5208.363 & 2.389 & 0.017 & 2201.561 & 22682.86 \\
\hline cancer & -10299.43 & 7743.982 & -1.330 & 0.184 & -25525.59 & 4926.74 \\
\hline stroknow & -14766.27 & 9527.453 & -1.550 & 0.122 & -33499.08 & 3966.548 \\
\hline heartevr & 1443.942 & 3926.156 & 0.368 & 0.713 & -6275.641 & 9163.525 \\
\hline workpay & -3845.317 & 13202.65 & -0.291 & 0.771 & -29804.29 & 22113.66 \\
\hline pay1five & 290.2537 & 96.86878 & 2.996 & 0.003 & 99.79091 & 480.7164 \\
\hline paylast & 998.9454 & 177.3632 & 5.632 & 0.000 & 650.2149 & 1347.676 \\
\hline annearn & 192.893 & 76.99281 & 2.505 & 0.013 & 41.51028 & 344.2758 \\
\hline hourswk & -61.75424 & 154.3011 & -0.400 & 0.689 & -365.14 & 241.6315 \\
\hline jobten & 415.0395 & 167.1194 & 2.483 & 0.013 & 86.45044 & 743.6285 \\
\hline ntwth000 & -1.020955 & 5.26662 & -0.194 & 0.846 & -11.37615 & 9.334238 \\
\hline numjobs 5 & 1716.783 & 1481.799 & 1.159 & 0.247 & -1196.721 & 4630.286 \\
\hline pension & 7688.727 & 4257.369 & 1.806 & 0.072 & -682.0843 & 16059.54 \\
\hline selfemp & -905.6941 & 5368.825 & -0.169 & 0.866 & -11461.84 & 9650.455 \\
\hline annage2 & -33.25068 & 185.7862 & -0.179 & 0.858 & -398.5424 & 332.041 \\
\hline weeksyr & 640.846 & 218.4704 & 2.933 & 0.004 & 211.291 & 1070.401 \\
\hline cons & 636990 & 497381 - 4 & 1. 281 & 0.201 & -340958.1 & 1614938 \\
\hline
\end{tabular}

\section{Nonmarried Women ( $\mathrm{N}=958$ )}

Dep. Var. Respondent's Own SSW at Normal Retirement

\begin{tabular}{|c|c|c|c|c|c|c|}
\hline & Coef. & Ed. Err. & t & $|t|$ & [95\% Conf. & Interval] \\
\hline age & -28057.83 & 12682.69 & -2.212 & 0.027 & -52947.65 & -3167.997 \\
\hline agesq & 261.2696 & 113.3066 & 2.306 & 0.021 & 38.90496 & 483.6343 \\
\hline educ & 400.2489 & 430.7319 & 0.929 & 0.353 & -445.0642 & 1245.562 \\
\hline white & 4369.277 & 2232.612 & 1.957 & 0.051 & -12.23346 & 8750.787 \\
\hline numkids & -2246.957 & 521.4404 & -4.309 & 0.000 & -3270.287 & -1223.628 \\
\hline walk $2 \mathrm{dv}$ & 2721.851 & 4303.325 & 0.632 & 0.527 & -5723.443 & 11167.14 \\
\hline carrydv & 4152.749 & 2832.103 & 1.466 & 0.143 & -1405.265 & 9710.763 \\
\hline cancer & 5445.667 & 3693.524 & 1.474 & 0.141 & -1802.89 & 12694.22 \\
\hline stroknow & -1614.946 & 9782.834 & -0.165 & 0.869 & -20813.8 & 17583.91 \\
\hline heartevr & 289.8103 & 3301.304 & 0.088 & 0.930 & -6189.013 & 6768.633 \\
\hline workpay & -14277.24 & 11092.27 & -1.287 & 0.198 & -36045.87 & 7491.399 \\
\hline paylfive & 66.01287 & 45.83834 & 1.440 & 0.150 & -23.94507 & 155.9708 \\
\hline paylast & 892.7003 & 134.2245 & 6.651 & 0.000 & 629.284 & 1156.117 \\
\hline annearn & 773.8802 & 85.39738 & 9.062 & 0.000 & 606.2875 & 941.4729 \\
\hline hourswk & 132.6382 & 108.2617 & 1.225 & 0.221 & -79.82582 & 345.1021 \\
\hline jobten & 496.1386 & 133.3307 & 3.721 & 0.000 & 234.4765 & 757.8006 \\
\hline ntwth000 & -2.124435 & 5.328161 & -0.399 & 0.690 & -12.58097 & 8.332103 \\
\hline numjobs 5 & 4293.726 & 1093.033 & 3.928 & 0.000 & 2148.643 & 6438.809 \\
\hline pension & 8738.329 & 2801.99 & 3.119 & 0.002 & 3239.41 & 14237.25 \\
\hline selfemp & 3885.041 & 4846.575 & 0.802 & 0.423 & -5626.384 & 13396.47 \\
\hline annage 2 & -144.357 & 135.1136 & -1.068 & 0.286 & -409.518 & 120.8041 \\
\hline weeksyr & 654.2103 & 216.0426 & 3.028 & 0.003 & 230.2257 & 1078.195 \\
\hline _cons & 771592.2 & 354616.8 & 2.176 & 0.030 & 75655.13 & 1467529 \\
\hline
\end{tabular}

Note: Number of observations reported in Appendix D as Sample 4. All analysis conducted with HRS sample weights; see text Dependent variables are the respondent's social security wealth as of the normal retirement age (var. 24) and (for married persons) the couple's social security wealth as of the respondent's normal retirement age (var. 23). All explanatory variables are as defined in Appendix B plus paylfive is pay on first 5-year job (/1000), and paylast is pay on last job (/1000) 


\section{Appendix D. Sample Size in Analysis}

Sample 1: EBF File

Sample 2: Sample 1 minus age ineligible minus those in receipt of SSDI in 1991

Married

Men $\quad 2326$

Women 2280

Nonmarried 1393

Men 413

Women $\quad 980$

Sample 3: Sample 2 minus married respondents where spouse not interviewed in HRS or spouse in current receipt of SSDI

Married

Men

Women

2217

Nonmarried (same as sample 1)

2118

Sample 4: Sample 2 minus those with missing data on regressors of Appendix $B$ or $C$

Married

Men

Women

2186

Nonmarried

2089

Men

1363

Women

405

958 